\title{
Buried Waste Integrated Demonstration FY 94 Deployment Plan
}

\author{
R. A. Hyde \\ S. Walker \\ M. M. Garcia \\ Published May 1994
Idaho National Engineering Laboratory
EG\&G Idaho, Inc.
Idaho Falls, Idaho 83415

\author{
Prepared for the \\ U.S. Department of Energy \\ Assistant Secretary for Environmental Restoration and Waste Management \\ Under DOE Idaho Operations Office \\ Contract DE-AC07-76ID01570
}




\section{DISCLAIMER}

This report was prepared as an account of work sponsored by an agency of the United States Government. Neither the United States Government nor any agency thereof, nor any of their employees, make any warranty, express or implied, or assumes any legal liability or responsibility for the accuracy, completeness, or usefulness of any information, apparatus, product, or process disclosed, or represents that its use would not infringe privately owned rights. Reference herein to any specific commercial product, process, or service by trade name, trademark, manufacturer, or otherwise does not necessarily constitute or imply its endorsement, recommendation, or favoring by the United States Government or any agency thereof. The views and opinions of authors expressed herein do not necessarily state or reflect those of the United States Government or any agency thereof. 


\section{DISCLAIMER}

Portions of this document may be illegible in electronic image products. Images are produced from the best available original document. 
Buried Waste Integrated Demonstration FY 94 Deployment Plan

EGG-WTD-11156

Prepared by

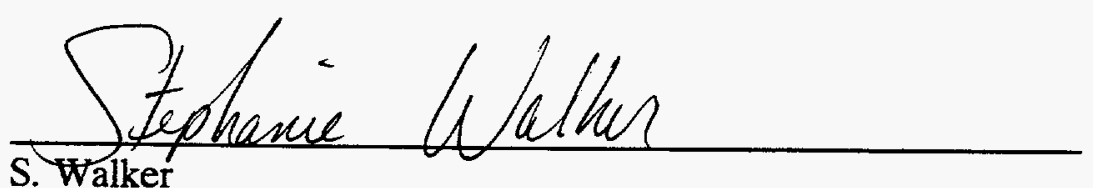

Senior Engineer

Reviewed by

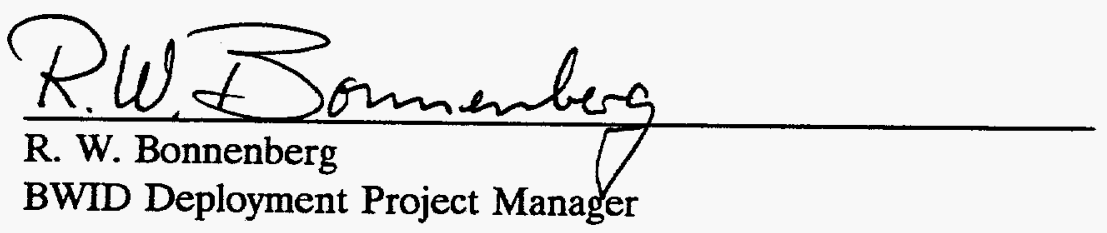

Approved by

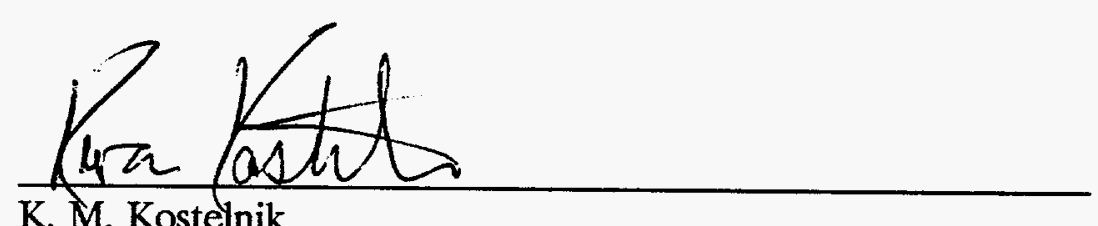

K. M. Kostelnik

BWID Coordinator
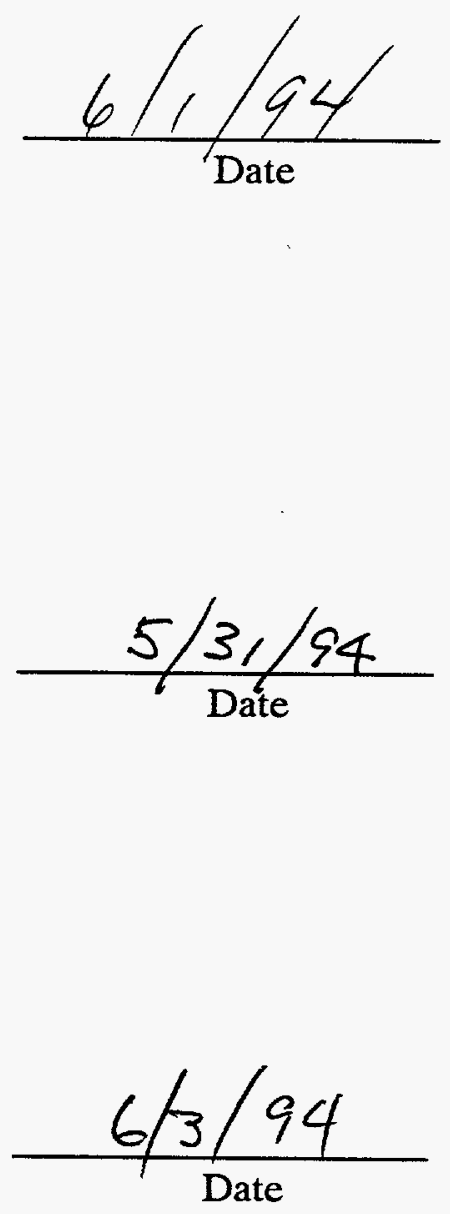


\section{ABSTRACT}

The Buried Waste Integrated Demonstration (BWID) is a program funded by the U.S. Department of Energy Office of Technology Development. BWID supports the applied research, development, demonstration, testing, and evaluation of a suite of advanced technologies that together form a comprehensive remediation system for the effective and efficient remediation of buried waste.

The fiscal year (FY) 1994 effort will fund thirty-eight technologies in five areas of buried waste site remediation: site characterization, waste characterization, retrieval, treatment, and containment/stabilization.

This document is the basic operational planning document for deployment of all BWID projects. Discussed in this document are the BWID preparations for INEL field demonstrations, INEL laboratory demonstrations, non-INEL demonstrations, and paper studies. Each technology performing tests will prepare a test plan to detail the specific procedures, objectives, and tasks of each test. Therefore, information specific to testing each technology is intentionally omitted from this document. 


\section{SUMMARY}

The Buried Waste Integrated Demonstration (BWID) program supports the development and demonstration, testing, and evaluation of a suite of technologies that, when integrated with commercially available baseline technologies, form a comprehensive system for the effective and efficient remediation of buried waste throughout the U.S. Department of Energy complex.

The FY 94 effort will deploy four field demonstrations at the Idaho National Engineering Laboratory (INEL) Cold Test Pit, and one at the Box Canyon Site near the INEL. These demonstrations include: Non-Intrusive Sensing of Environmentally Important Objects and Species; INEL Very Early Time Domain EM (VETEM); BWID Dig Face Characterization; Innovative Grout Demonstration; and Monolithic Confinement.

Laboratory demonstrations to be performed at the INEL include as follows: Imaging Infrared Interferometer; Preparation of Rapid TRU Monitoring Lab for Field Deployment; Real Time Monitoring of Transuranic Contaminated Dust; High Speed Digital Radiography and Computed Tomography of Waste Drums; Cryogenic Cutting; Cooperative Telerobotic Retrieval; System Health Monitoring; and Ice Electrode.

Additional demonstrations are planned at non-INEL facilities, such as other government facilities, university laboratories, and vendor sites. The non-INEL projects include: Waste Conveyance for Buried Waste Retrieval; Innovative End Effector; High Resolution Imaging of Buried Waste using Holographic Impulse Radar Assay; Radiological and Hazardous Material Measurement System (RHMMS); Field Demonstration of Characterization Technologies; Assay of Contaminated Soils from Buried Waste Pits; Electrothermal Hollow Cathode Discharge Spectrometry: Diode LaserBased Spectrometries Applied in a Furnace Atomization Nonthermal Emission Source; Improved TRU Waste Assay: Combined Thermal/Epithermal Neutron (CTEN); Active and Passive Computed Tomography Gamma Assay of Radioactive Waste; Full-Scale Remote Retrieval; 3RAW Remote Excavation Oak Ridge National Laboratory (ORNL); Arc Melter Vitrification; Secondary Treatment of BWID Offgas using Nonthermal Plasma; STRATEX for treatment of soils; and Graphite DC Arc and In Situ Real Time Measurements.

The remaining BWID projects consist of office research (paper studies and computer simulations) and technical review meetings. The following projects fall into this category: NonIntrusive Characterization Studies; Evaluation of Platforms for Electromagnetic and Magnetic Sensors; Electromagnetic Imaging as Applied to Mapping and Characterization; Virtual Environment Generation of Buried Waste; BWID Geophysics Workshop; Contaminated Material Excavation Handling and Retrieval System; Hazardous Chemical Waste Separation at RWMC Excavation Sites; Modeling of Thermal Plasma Arc Technology; Ground Penetrating Radar (GPR) Research Consortium; and $3 D$ Simulation.

This document defines the requirements for the demonstrations to be conducted in the field in FY 94. Technologies to be demonstrated in the field in FY 95 or beyond are not considered field demonstrations in this document and fall instead into the category of the work performed during this fiscal year. The basic requirements to support the demonstration of other technologies are also presented, but more briefly. Requirements such as safety and environmental 
protection are currently defined by facility managers and organizations responsible for the facilities in which the work will be performed. However, BWID is responsible for defining requirements for the Cold Test Pit and the Box Canyon Site.

During FY 94, it is anticipated that changes to the planned activities may occur. Each of these changes will be reviewed by the BWID Deployment Team to determine the necessary modifications to the planned activities as well as to this document. 


\section{CONTENTS}

ABSTRACT $\ldots \ldots \ldots \ldots \ldots \ldots \ldots \ldots \ldots \ldots \ldots \ldots \ldots \ldots \ldots \ldots \ldots \ldots \ldots \ldots \ldots \ldots$

SUMMARY $\ldots \ldots \ldots \ldots \ldots \ldots \ldots \ldots \ldots \ldots \ldots \ldots \ldots \ldots \ldots \ldots \ldots \ldots \ldots$

ACRONYMS $\ldots \ldots \ldots \ldots \ldots \ldots \ldots \ldots \ldots \ldots \ldots \ldots \ldots \ldots \ldots \ldots \ldots \ldots \ldots \ldots \ldots \ldots \ldots$

1. INTRODUCTION $\ldots \ldots \ldots \ldots \ldots \ldots \ldots \ldots \ldots \ldots \ldots \ldots \ldots \ldots \ldots \ldots \ldots \ldots$

1.1 Purpose and Scope $\ldots \ldots \ldots \ldots \ldots \ldots \ldots \ldots \ldots \ldots \ldots \ldots \ldots \ldots \ldots \ldots \ldots$

1.2 Historical Perspective $\ldots \ldots \ldots \ldots \ldots \ldots \ldots \ldots \ldots \ldots \ldots \ldots \ldots \ldots \ldots \ldots$

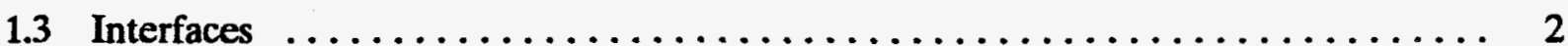

1.4 Technology Descriptions $\ldots \ldots \ldots \ldots \ldots \ldots \ldots \ldots \ldots \ldots \ldots \ldots \ldots \ldots \ldots \ldots$

1.4.1 Site Characterization Technologies $\ldots \ldots \ldots \ldots \ldots \ldots \ldots \ldots \ldots \ldots \ldots$

1.4.2 Waste Characterization Technologies .................. 7

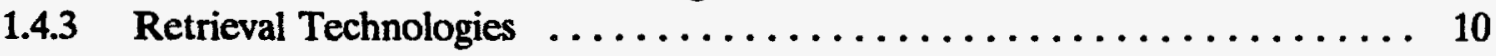

1.4 .4 Treatment Technologies $\ldots \ldots \ldots \ldots \ldots \ldots \ldots \ldots \ldots \ldots \ldots \ldots \ldots$

1.4.5 Containment/Stabilization Technologies $\ldots \ldots \ldots \ldots \ldots \ldots \ldots \ldots \ldots \ldots$

2. ORGANIZATION AND RESPONSIBILITIES $\ldots \ldots \ldots \ldots \ldots \ldots \ldots \ldots \ldots \ldots \ldots$

2.1 Organization Chart $\ldots \ldots \ldots \ldots \ldots \ldots \ldots \ldots \ldots \ldots \ldots \ldots \ldots \ldots \ldots \ldots \ldots$

2.2 Personnel Responsibilities $\ldots \ldots \ldots \ldots \ldots \ldots \ldots \ldots \ldots \ldots \ldots \ldots \ldots \ldots \ldots \ldots$

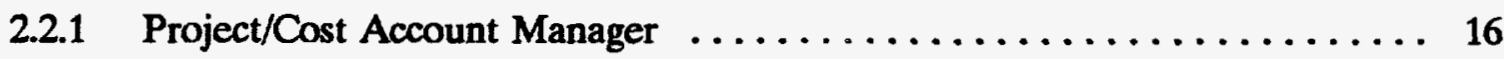

2.2.2 Integrated Demonstration Coordinator $(\mathrm{W} C) \ldots \ldots \ldots \ldots \ldots \ldots$

2.2.3 Technical Liaison .......................... 16

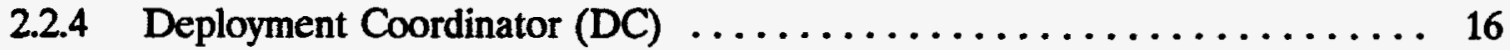

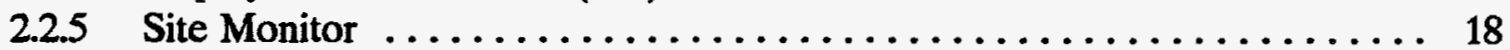

3. ESH\&Q BWID Deployment Support $\ldots \ldots \ldots \ldots \ldots \ldots \ldots \ldots \ldots \ldots \ldots \ldots$

3.1 Description of BWID ESH\&Q Deployment Support $\ldots \ldots \ldots \ldots \ldots \ldots \ldots$

3.2 Environmental Documentation $\ldots \ldots \ldots \ldots \ldots \ldots \ldots \ldots \ldots \ldots \ldots \ldots \ldots$

3.2.1 National Environmental Policy Act Documentation .............. 19

3.2.2 Storm Water Pollution Prevention Plans $\ldots \ldots \ldots \ldots \ldots \ldots \ldots \ldots \ldots \ldots$

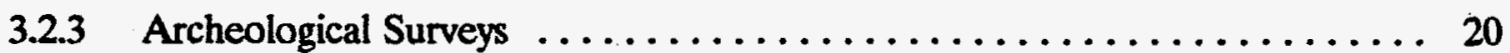

3.2.4 Threatened and Endangered Species Surveys ................. 20

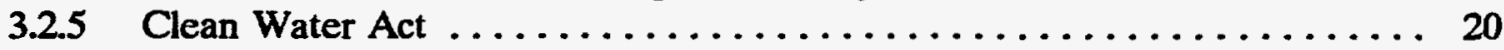




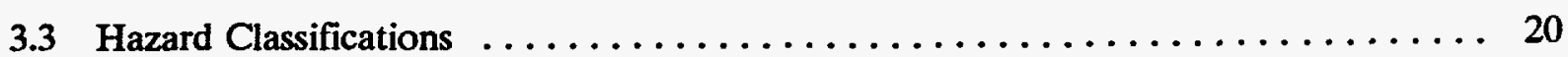

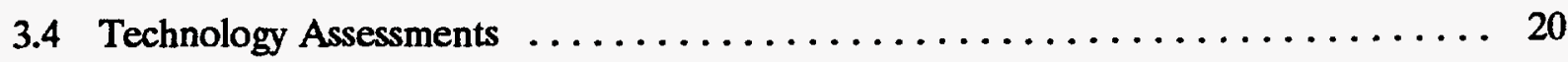

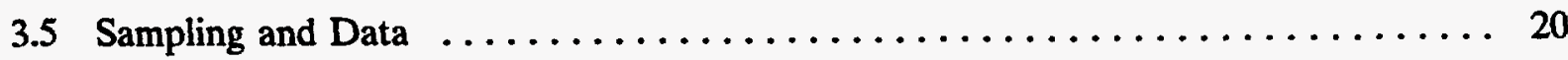

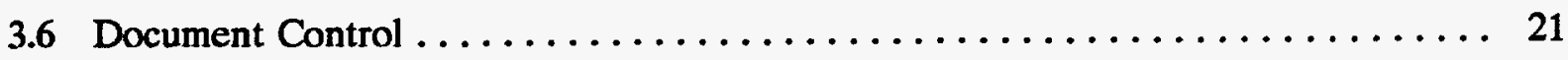

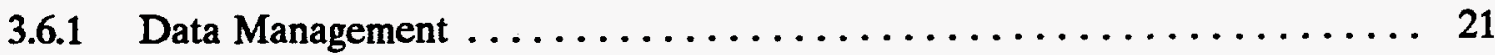

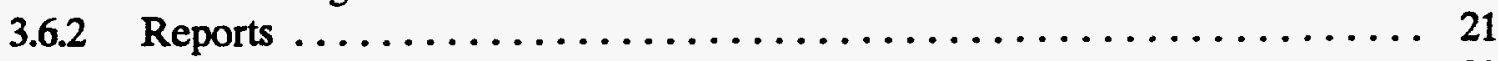

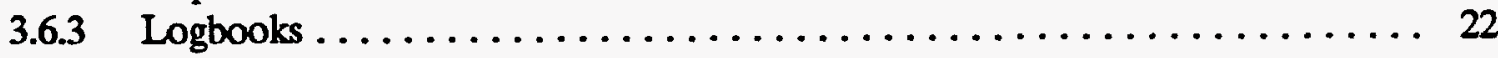

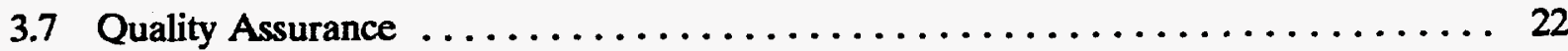

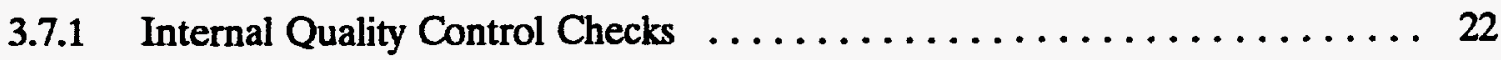

3.7.2 Performance and System Audits ...................... 23

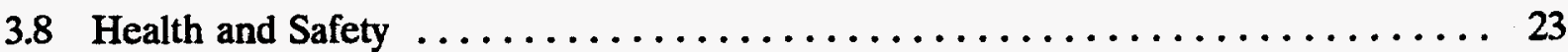

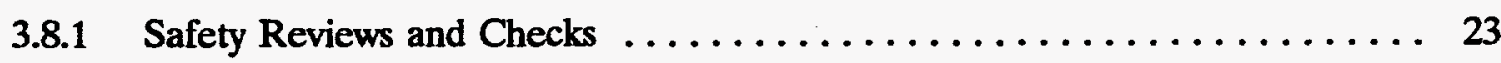

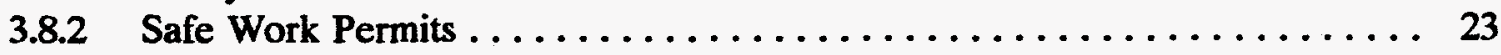

3.9 Residuals Management and Waste Minimization $\ldots \ldots \ldots \ldots \ldots \ldots \ldots \ldots$

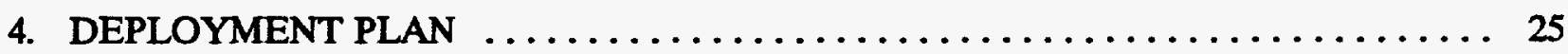

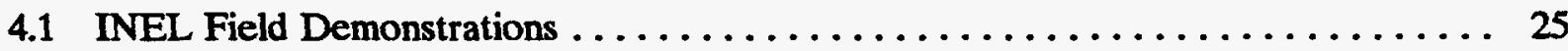

4.1.1 Facilities $\ldots \ldots \ldots \ldots \ldots \ldots \ldots \ldots \ldots \ldots \ldots \ldots \ldots \ldots \ldots \ldots \ldots \ldots \ldots \ldots \ldots \ldots \ldots, 25$

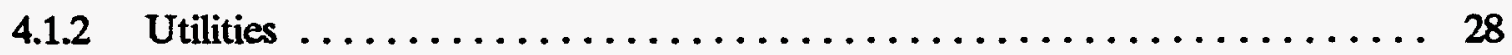

4.1.3 Transportation $\ldots \ldots \ldots \ldots \ldots \ldots \ldots \ldots \ldots \ldots \ldots \ldots \ldots \ldots \ldots \ldots \ldots \ldots \ldots \ldots \ldots \ldots, 28$

4.1.4 Site Restoration .............................. 29

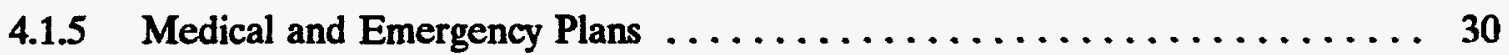

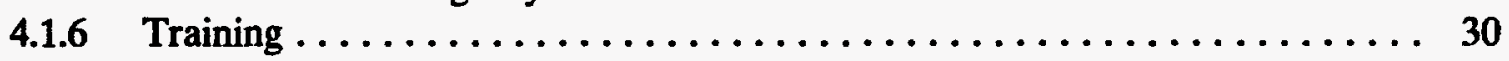

4.1.7 Waste Disposal $\ldots \ldots \ldots \ldots \ldots \ldots \ldots \ldots \ldots \ldots \ldots \ldots \ldots \ldots, 31$

4.2 INEL Laboratory Demonstrations $\ldots \ldots \ldots \ldots \ldots \ldots \ldots \ldots \ldots \ldots \ldots \ldots \ldots \ldots$

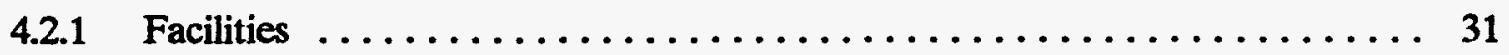

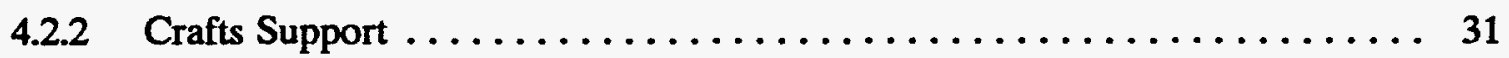

4.3 Non-INEL Demonstrations $\ldots \ldots \ldots \ldots \ldots \ldots \ldots \ldots \ldots \ldots \ldots \ldots \ldots \ldots \ldots$

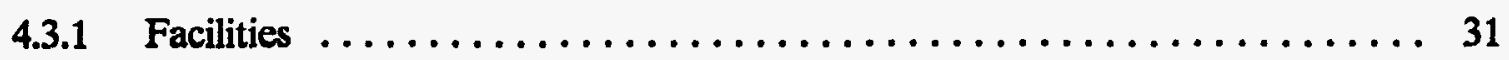

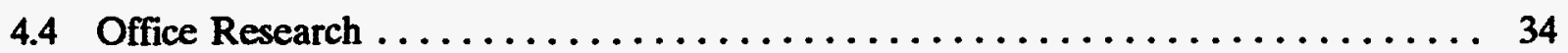




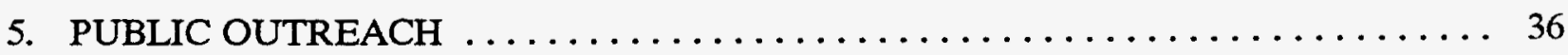

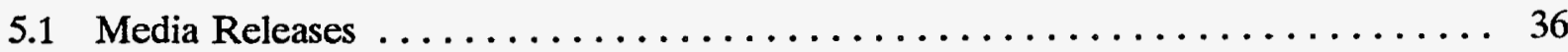

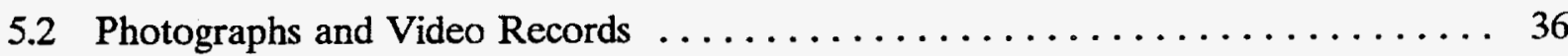

5.3 Open House and Equipment Display $\ldots \ldots \ldots \ldots \ldots \ldots \ldots \ldots \ldots \ldots \ldots \ldots \ldots \ldots \ldots$

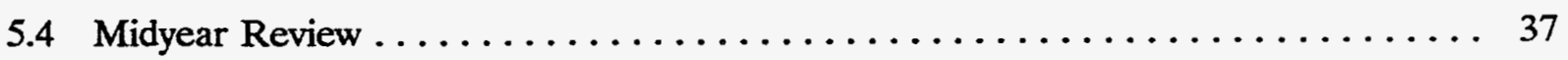

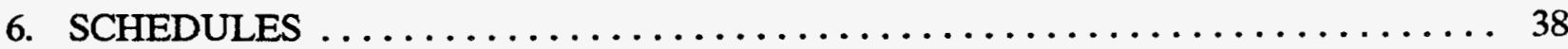

6.1 BWID Deployment Team Activities Schedule $\ldots \ldots \ldots \ldots \ldots \ldots \ldots \ldots \ldots$

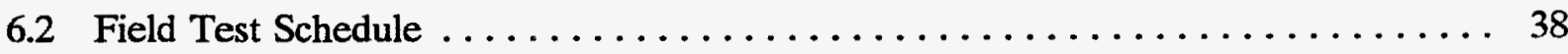

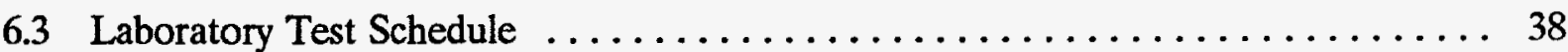

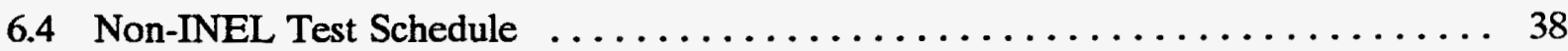

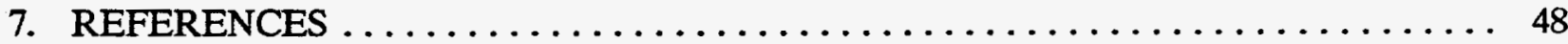

FIGURES

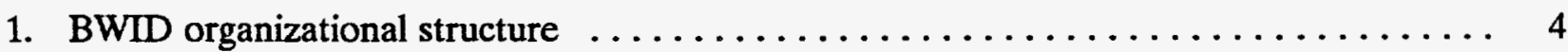

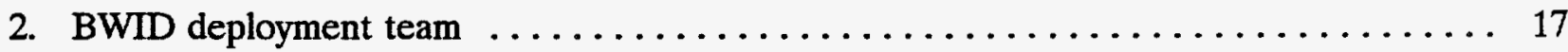

3. Field demonstrations performed at the INEL $\ldots \ldots \ldots \ldots \ldots \ldots \ldots \ldots \ldots \ldots \ldots$

4. Laboratory tests performed at the INEL $\ldots \ldots \ldots \ldots \ldots \ldots \ldots \ldots \ldots \ldots \ldots \ldots, 32$

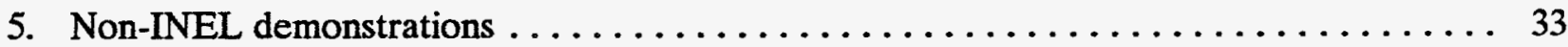

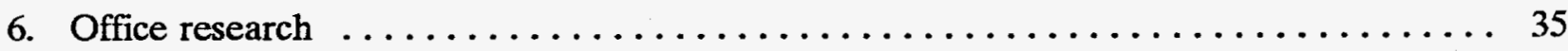

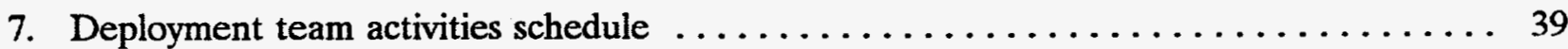

8. INEL field deployment schedule $\ldots \ldots \ldots \ldots \ldots \ldots \ldots \ldots \ldots \ldots \ldots \ldots \ldots \ldots, 42$

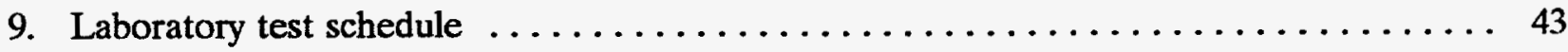

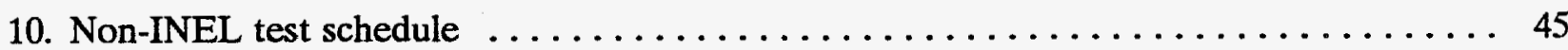




\section{TABLES}

1. Schedule for technology assessments and preparedness reviews $\ldots \ldots \ldots \ldots \ldots \ldots \ldots$

2. Schedule for guidance and ESH\&Q plans $\ldots \ldots \ldots \ldots \ldots \ldots \ldots \ldots \ldots \ldots \ldots \ldots$ 


\section{ACRONYMS}

A\&P CT active and passive computed tomography

AGV automatically guided vehicle

ANSI American National Standards Institute

ASME American Society of Mechanical Engineers

BLM Bureau of Land Management

BRC below regulatory concern

BWID Buried Waste Integrated Demonstration

CAM continuous air monitor

CCU Contamination Control Unit

CFA Central Facilities Area

CMEHRS Contaminated Material Excavation Handling and Retrieval System

CT computed tomography

CTEN combined thermal/epithermal neutron

CTP Cold Test Pit

CX Categorical Exclusion

DC Deployment Coordinator

DDT differential-dieaway technique

DOE U.S. Department of Energy

DOE-HQ U.S. Department of Energy Headquarters

DOE-ID U.S. Department of Energy Idaho Operations Office

DQOs Data Quality Objectives

DR digital radiography

EAP Environmental Assessment and Permitting 
EM Electromagnetic

EPA Environmental Protection Agency

ER/WM Environmental Restoration and Waste Management

FANES Furnace Atomization Nonthermal Excitation Spectrometric

FTIR fourier transform infrared

FY fiscal year

GGSS Gravity Gradiometer Survey System

GPH ground penetrating holographic

GPR Ground Penetrating Radar

GTCC Greater than Class C

HEPA high efficiency particulate air (filter)

HPGe high purity germanium

HVPMs high vapor pressure metals

ID Integrated Demonstration

IDC Integrated Demonstration Coordinator

INEL Idaho National Engineering Laboratory

IP Integrated Program

ISU Idaho State University

ISV in situ vitrification

LIBS laser-induced breakdown spectroscopy

LLW low-level radioactive waste

LSV low signature vehicle

MIT Massachusetts Institute of Technology 
MTR Materials Test Reactor

NBRC North Boulevard Robotics Complex

NEPA National Environmental Policy Act

NOAA National Oceanic and Atmospheric Association

NQA Nuclear Quality Assurance

NTP Nonthermal Plasma

ORNL Oak Ridge National Laboratory

OSHA Occupational Safety and Health Administration

OTD Office of Technology Development

P/CAM project/cost account manager

PI Principal Investigator

PPE Personnel Protective Equipment

QA Quality Assurance

QPP Quality Program Plan

RCS Remote Characterization System

RES Remote Excavation System

RTDM real time dust monitor

RTML Rapid Transuranic Monitoring Laboratory

RWMC Radioactive Waste Management Complex

SAR Safety Analysis Report

SBPD simulation-based planning design

SDA Subsurface Disposal Area

SHM\&P System Health Monitoring and Prediction Program

SWPPP Storm Waste Pollution Prevention Plan 
TAN Test Area North

TARG Technical Academia Review Group

TARs Technology Assessment Reports

TEM transient electromagnetic

TLs technical liaisons

TMG Tensor Magnetic Gradiometer

TP\&SR Technology Preparedness and Status Report

TRA Test Reactor Area

TRU Transuranic

TSG Technical Support Group

TTP Technical Task Plan

VETEM Very Early Time Domain Electromagnetics

VOC Volatile Organic Compound

WCC Warning Communications Center 


\section{Buried Waste Integrated Demonstration FY 94 Deployment Plan}

\section{INTRODUCTION}

The U.S. Department of Energy (DOE) Office of Technology Development (OTD) Buried Waste Integrated Demonstration (BWID) program is supporting the development, demonstration, testing, and evaluation of a suite of technologies that, when integrated with commercially available baseline technologies, form a comprehensive system for the effective and efficient remediation of buried waste throughout the DOE complex.

The FY 94 effort will deploy five major INEL field demonstrations, eight INEL laboratory demonstrations, and sixteen projects at non-INEL facilities. The nine remaining technologies fall into the categories of office research (paper studies and computer simulations) and technical review meetings.

\subsection{Purpose and Scope}

This document defines the requirements for the technologies to be demonstrated in the field in FY 94. Technologies to be demonstrated in FY 95 or beyond are not considered field demonstrations in this planning document and fall instead into the category of the work performed during this fiscal year. The basic requirements to support the demonstration of other technologies are also presented, but more briefly. Requirements such as safety and environmental protection are currently defined by facility managers and organizations responsible for the facilities in which the work will be performed. However, BWID is responsible for defining requirements for the Cold Test Pit (CTP) and the Box Canyon Site that are consistent with the EG\&G Idaho Safety Manual.

Soon after approval of the Technical Task Plans (TTPs), the Principal Investigators (PIs), were required to submit a Technology Preparedness and Status Report (TP\&SR) and Preparedness Checklist and Action Plan for review by the BWID Deployment Team and others. The Deployment Team consists of BWID and functional support staff with expertise in the areas of facility and operational planning, environmental compliance, safety, health, and quality. The information in these documents and interviews conducted by the Deployment Team, with the PIs, provided the basis for rreparing this document and planning deployment of the thirty-eight technologies funded $B$ BWD.

\subsection{Historical Perspective}

Funded by the DOE Office of Technology Development (OTD), the goal of the BWID program is to provide innovative technologies in a timely manner for the DOE Environmental Restoration/Waste Management (ER/WM) Program. These technologies are being developed and demonstrated to assist ER in remediating the various buried waste sites throughout the DOE complex. 
The amount of buried waste located throughout the DOE complex is estimated to be approximately 2.1 million cubic meters. The majority of this waste is located at the Hanford Site, Savannah River Site, INEL, Los Alamos National Laboratory, Oak Ridge National Laboratory, and Rocky Flats Plant. The wastes at these sites are buried or stored in trenches, pits, buildings, storage pads, or other structures.

Approximately half of all DOE buried waste was disposed of before 1970. At that time, disposal regulations permitted the commingling of various types of waste [i.e., transuranic (TRU), low-level radioactive waste ( $L L W$ ), and hazardous]. As a result, much of the buried waste throughout the DOE complex is believed to be contaminated with both hazardous and radioactive materials. DOE buried waste typically includes TRU, LLW, hazardous waste per 40 CFR 261, greater-than-class-C (GTCC) waste per 10 CFR 61 55, mixed TRU waste, and mixed LLW. Interstitial soils are also believed to be contaminated as a result of these disposal practices, which significantly increases the volume of materials requiring remediation.

Typical buried waste includes construction and demolition materials (e.g., lumber, concrete blocks, and steel plates), laboratory equipment (e.g., hoods, desks, tubing, and glassware), process equipment [e.g., heat exchangers, valves, ion exchange resins, high efficiency particulate air (HEPA) filters], maintenance equipment (e.g., hand tools, cranes, oils and greases), and decontamination materials (e.g., paper, rags, and plastic bags).

A variety of disposal containers were used and included steel drums, cardboard cartons, and wooden boxes. Larger individual items were disposed of separately as loose trash. Degradation of the waste containers is believed to have resulted in contamination of the immediate surrounding soil.

\subsection{Interfaces}

The DOE OTD effort focuses resources through Integrated Programs (IPs) and Integrated Demonstrations (IDs) that are technology and problem specific. IDs and IPs have established Program Planning, Technical Support Groups (TSGs), and a Technical Academia Review Group (TARG) to improve strategic planning efforts and technical integrity.

The BWID Program Planning Group has been structured to include representatives of the Environmental Restoration Programs at DOE sites with significant amounts of buried waste, representatives from the Environmental Protection Agency (EPA), Region 10, and the State of Idaho.

TSGs consist of the anticipated end-users of a technology, such as ER/WM. Members of the TARGs include university and industry experts in the technology. Their purpose is to provide independent peer review of each project.

Systematic communication between BWID, the INEL Buried Waste Program, and implementation of a systems analysis process, ensures that technology gaps are identified, appropriate technology demonstrations are funded, and technology transfer is facilitated. 
Formal and informal communication has been established between the BWID project office and PIs. Formal communications include weekly and monthly reports as well as quarterly technical review meetings.

\subsection{Technology Descriptions}

The thirty-eight technologies funded by BWID in FY 94 are described below. These technologies are divided in the five main categories for technology type (site characterization, waste characterization, retrieval, treatment, and containment/stabilization) and again for location of demonstration or primary FY 94 effort. The BWID organizational structure showing all BWID-funded technologies is shown in Figure 1.

\subsubsection{Site Characterization Technologies}

1.4.1.1 INEL Field Demonstrations. INEL field demonstrations of site characterization technologies include as follows.

1.4.1.1.1 Very Early Time Domain EM NETEM)-This research, initiated in FY 94, will endeavor to design a high resolution electromagnetic (EM) imaging system for shallow environmental problems, specifically for identifying buried objects by shape, orientation, and location at waste sites. PIs for the project include Louise Pellerin and Victor Labson of the USGS and M. Cathy Pfeifer of the INEL. Contributions to the project will be made by the University of California-Berkeley, the University of Arizona, the University of Utah, the Colorado School of Mines, RUST Geotech, Inc., Lawrence Berkeley Laboratory, Oak Ridge National Laboratory, and Sandia National Laboratories.

By using the VETEM system to collect and interpret data from the shallow subsurface, the demonstration hopes to prove an overall effectiveness by operating between low frequency EM induction and ground penetrating radar (GPR) frequencies to allow use at sites where GPR alone has yielded little success. This technology will be demonstrated at the INEL Cold Test Pit in May and June of 1994.

1.4.1.1.2 BWID Dig-face Characterization-Testing of this technology will be done in FY 94 with the purpose of providing constant surveillance and screening of all categories of hazards during dig-face excavation. Nick E. Josten and Skip Snyder of RUST Geotech, Inc. are the PIs.

The purpose of the testing is to develop a system for deploying sensors at the dig face of a buried waste retrieval process. Once developed, this system would allow for continuous characterization as the retrieval proceeds, thus increasing safety of operations. Current activities include testing of the robotic gantry crane system, which will deploy the sensors; and field tests in a simulated test trench at the INEL Cold Test Pit. This technology will be demonstrated at the INEL Cold Test Pit in July and August of 1994.

1.4.1.2 INEL Laboratory Projects. BWID funded projects of site characterization technologies that will be performed in INEL laboratories for FY 94 include as follows. 


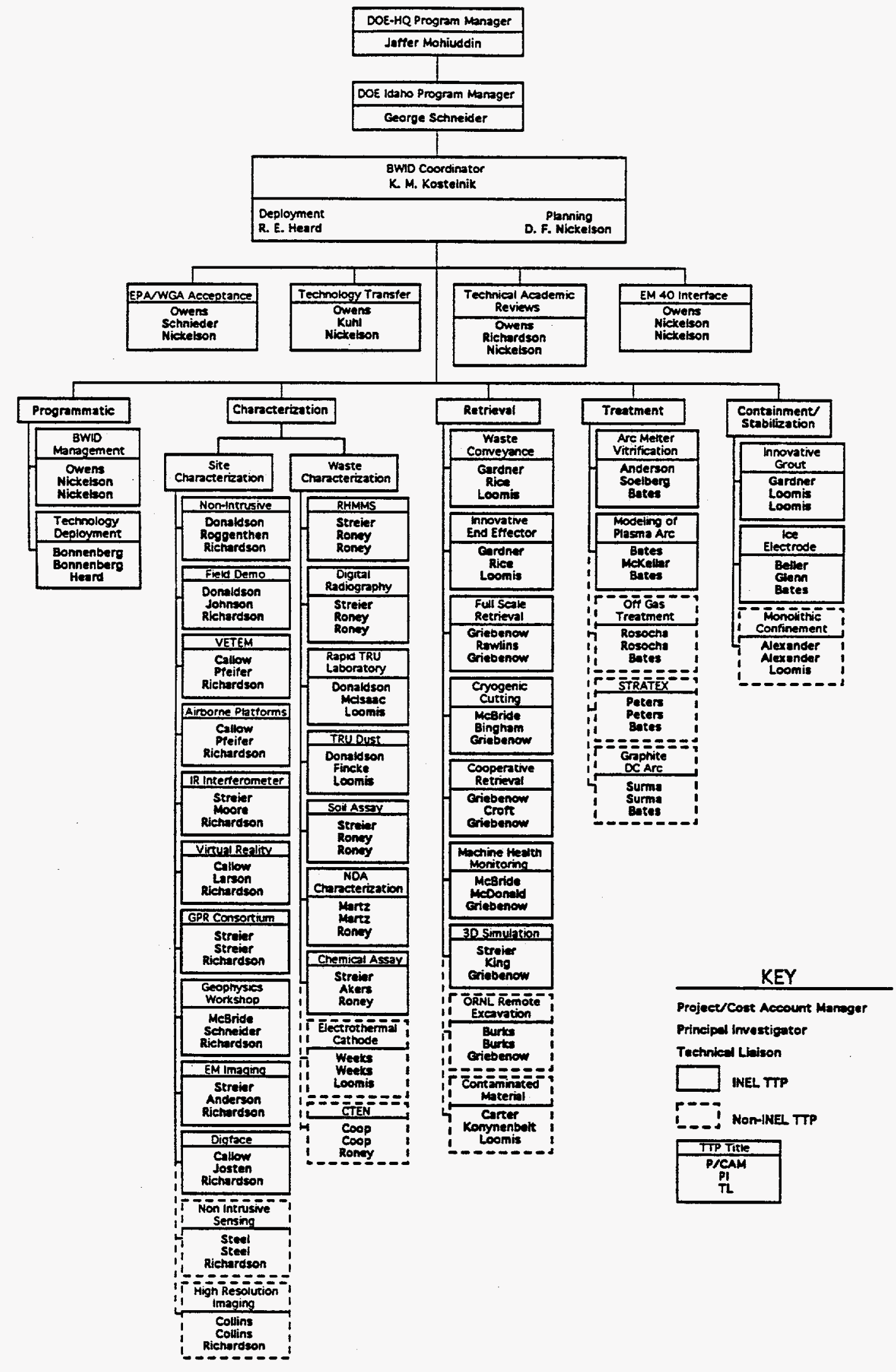

Figure 1. BWID organizational structure. 
1.4.1.2.1 Imaging Infrared Interferometer-This technology, initiated in FY 94, will develop and test an infrared imaging system capable of real-time wide area volatile organic compound (VOC) monitoring of a waste remediation site. Glenn A. Moore of INEL is the PI with much of the project being performed by Physical Sciences, Inc.

FY 94 research will concentrate on producing a design specification that employs open-path fourier transform infrared (FTIR) spectrometers for identifying VOCs. Once constructed, a prototype standoff system will provide multispectral imaging through use of mirror spacing, which produces continuous images of a field of view with high sensitivity for identifying VOCs. This technology will not be demonstrated in FY 94.

1.4.1.3 Non-INEL Projects. Site characterization technologies whose efforts will be performed in facilities other than the INEL include as follows.

\subsection{High Resolution Imaging of Buried Waste Using Holographic Impulse}

Radar Array-This research was initiated in FY 94 to develop and demonstrate a field prototype and test a ground penetrating holographic (GPH) radar system for site characterization application in low conductivity soils. The PIs are H. Dale Collins and R. P. Gribble of Pacific Northwest Laboratories.

The GPH radar system will employ a tapered slot antenna bistatic array system, suitable for analyzing at all depths of low conductivity soils, to scan subsurface target data to provide a three-dimensional holographic image. Initial efforts will be concentrated in fabricating and developing the array and imaging software before demonstration of the array vehicle at PNL. A demonstration of this technology is planned for the Cold Test Pit in September 1995.

\subsection{Field Demonstration of Characterization Technologies-Initiated in} FY 93, this proposed action is to conduct laboratory tests necessary to acquire sufficient data to evaluate the inverse scattering ground penetrating radar (GPR) algorithm developed by Techniscan that improves images of buried objects. The PI is Steven Johnson of Techniscan.

If successful, this algorithm has application for processing GPR data to locate and identify buried waste containers at the INEL's RWMC and other DOE sites. The objectives for FY 94 are to (a) calibrate a laboratory-scale scanner and associated data collection equipment using known objects located in air, (b) containers buried in sand, and (c) collect inverse scattering data and produce images of simulated waste containers buried in soil supplied by the INEL. These tests will take place at the University of Utah under controlled laboratory conditions.

1.4.1.4 Office Research and Technical Review Meetings. Site characterization projects that will require no field or laboratory work in FY 94 include as follows.

\subsection{Platforms for Electromagnetic and Magnetic Sensors-Initiated in} FY 94, research efforts are concentrated on evaluating potential electromagnetic and magnetic sensor mobilization platforms for buried waste sites. The PIs are M. Cathy Pfeifer of the INEL, and Louise Pellerin and Victor F. Labson of the USGS. 
A study has been initiated to determine platform evaluation criteria with the intention of providing guidance for selecting platforms appropriate for a specific site. Parameters addressed in the final report will include cost of deployment, ease of use, availability, and suitability to buried waste problems. This technology will not be demonstrated in FY 94.

1.4.1.4.2 Virtual Environment Generation of Buried Waste-This technology was initiated in FY 94 to investigate the feasibility of developing a computer generated virtual environment for buried waste sites. The PIs are Tom K. Larson and L. Eric Greenwade of the INEL.

Generation of virtual environments can be an important tool for site characterization analysis, strategy, and design of actual remediation efforts and systems. Using a simulation-based planning design (SBPD) concept (which applies computer simulation tools into the engineering process) researchers will use site characterization data and perform physics modeling to develop a prototype virtual environment.

\subsection{Electromagnetic Imaging as Applied to Mapping and}

Characterization-This technology will be used to demonstrate the use of three complementary electromagnetic processing and imaging techniques in the delineation and characterization of buried waste sites. The PI is H. T. Anderson of the Colorado School of Mines.

Electromagnetic surveying provides a quick geoelectric image of a buried waste site subsurface. The three imaging methods will be applied to high resolution, multi-component transient electromagnetic (TEM) data for use at the INEL Cold Test Pit. This testing will provide data for recommending an optimum set of acquisition parameters to support a TEM system.

1.4.1.4.4 BWID Geophysics Workshop-The purpose of this workshop is to highlight some of the geophysical technologies, diverse methods, and nonintrusive characterization technologies that have been used in BWID-funded demonstrations. This forum will illicit an exchange of information between PIs, BWID personnel, the Office of Technology Development, and external experts. The PI is Robert E. Heard of the INEL.

The workshop will be the second in a series of workshops (first conducted to review FY 93 work) sponsored by BWID and will present ongoing research and results of FY 94 testing. These reviews and presentations will be a catalyst for discussing characterization issues and developing a baseline for BWID's role in obtaining optimal results in future testing and demonstrations. The workshop will be held at the INEL in FY 94.

1.4.1.4.5 Non-Intrusive Characterization Studies-Initiated in FY 93, this study has focused on assessing existing underground radar performance and mineralogy data at the INEL's RWMC. David Parrish and W. M. Roggenthen, South Dakota School of Mines and Technology, are serving as Principal Investigators.

Research findings on the dielectric properties and attenuation as a function of radar wave frequency are scheduled for publication in FY 94. The PIs hope to show that the radar survey of RWMC will provide estimates in regard to depth to the basalt at pit boundaries, depth to 
overburden/waste interface, and location of the original excavation boundaries, as well as other waste sites, particularly those with high clay content soils.

1.4.1.4.6 Ground Penetrating Radar Research Consortium-The objective of this research is to evaluate existing ground penetrating radar (GPR) technologies, including current research efforts, and recommend and initiate, after approval, a proposed research program to evaluate new GPR systems (specifically, the Coleman-Blackhawk system). Principal Investigator for the project is Jeff Daniels of Ohio State University. The draft evaluation report will also include information and evaluation of USGS and BOM proposals.

\subsubsection{Waste Characterization Technologies}

1.4.2.1 INEL Field Demonstrations. INEL field demonstrations of waste characterization technologies include as follows.

1.4.2.1.1 Non Intrusive Sensing of Environmentally Important Objects-The objective of this task is to develop an improved system for nonintrusive site characterization and object location at BWID sites through the measurement and interpretation of a Tensor Magnetic Gradiometer (TMG). In FY 92, a full tensor magnetic gradiometer was simulated by measuring the outputs from a single-beam gradiometer oriented in different orthogonal directions. During FY 93, an eight element magnometer/gradiometer was assembled and supporting software developed. To date, efforts have been to make precision static measurements. The plan for FY 94 is to perform the same function in a dynamic mode at the INEL Cold Test Pit. The PI is C. G. Schwenk of RUST Geotech Inc.

1.4.2.2 INEL Laboratory Projects. BWID-funded projects of waste characterization technologies that will be performed in INEL laboratories for FY 94 include as follows.

\subsection{Preparation of Rapid TRU Monitoring Laboratory for Field}

Deployment-Research will continue on this technology during FY 94 to enhance the capabilities of the Rapid Transuranic Monitoring Laboratory (RTML). The PIs are Charles V. McIsaac, Claude W. Siil, and Robert J. Gehrke of the INEL.

The RTML is intended to provide rapid onsite sample analysis capabilities for identifying TRU contamination and for quickly evaluating steps for remedial action. The RMTL is housed in two mobile trailers, one of which contains a laboratory and the other containing the monitoring equipment. The primary advantage of a fully operational unit is a cost reduction when compared to conventional methods of sample analysis. The RTML can process over 100 soil, filter, and smear samples per day for about $\$ 30$ per sample. During FY 94 , the laboratory capability will be enhanced by examining in-field beta detection schemes.

1.4.2.2.2 Real Time Monitoring of Transuranic Contaminated Dust-The FY 94 demonstration of this project will show the researcher's work in developing a real time in situ instrument for monitoring TRU contaminated dust. The PIs are Judy K. Partin, James R. Fincke, and Charles V. McIsaac of the INEL. 
To evaluate dust for TRU contamination, researchers have incorporated alpha continuous air monitors (CAMs) and the laser-induced breakdown spectroscopy (LIBS) technology into a real time dust monitor (RTDM). This measurement will allow alleviation of major potential contamination problems by providing quick and accurate determination of the presence of dust and alpha emitting contaminants. The RTDM is also capable of detecting many hazardous heavy metals that have strong emission in visible and ultraviolet regions. This technology will be laboratory tested in June 1994.

\subsection{High Speed Digital Radiography and Computed Tomography of Waste}

Drums-This technology will demonstrate the capabilities and applications of a commercial scanner for high throughput digital radiography (DR) and transmission computed tomography (CT) as it applies to the retrieve and treat option of site remediation. Timothy J. Roney of the INEL is the PI and will work in conjunction with Scientific Measurement Systems, Inc.

DRCT scanners use $\mathrm{x}$-rays to measure waste container density and to view waste drum contents (particularly 55-gal disposal drums). High throughput is used to obtain quantitative information by enhancing the detection system to an area-type detector versus a linear array, which allows for the density measurement and the viewing capability. This scanning capability is considered a viable tool because it can be used to characterize waste at various stages of the retrieval and treatment process, particularly during the assay process. Demonstration of this technology is planned for FY 96.

1.4.2.3 Non-INEL Projects. Waste characterization technologies whose efforts will be performed at facilities other than the INEL include as follows.

\subsection{Electrothermal Hollow Cathode Discharge Spectrometry: Diode Laser-Based Spectrometries Applied in a Furnace Atomization Nonthermal Emission} Source-This technology will demonstrate in FY 94 a prototype electrothermal hollow cathode discharge spectroscopy system for use in assessing radioactive or hazardous contamination problems at buried waste sites. The PIs are Stephan Weeks and Martin Edelson of Ames Laboratory at the University of Iowa.

By combining diodide laser-based absorption, fluorescence, and optogalvanic methods used by the researchers at Ames with a Furnace Atomization Nonthermal Excitation Spectrometric (FANES) system (a versatile tool for elemental analysis), a prototype will be developed capable of isotopic analysis of actinides and for characterizing RCRA metals. Sufficiently compact for use in an onsite laboratory, this technology will be capable of providing quick and accurate qualitative measurements of waste samples taken from buried waste sites to determine hazardous constituents.

1.4.2.3.2 Improved Transuranic Waste Assay: CTEN-Initiated in FY 93, this technology will be used to develop an enhancement to the currently used differential-dieaway technique (DDT), which uses thermal neutrons to interrogate for fissile isotopes in waste drums. The combined thermal/epithermal neutron (CTEN) method will be similar to DDT but will interrogate the sample with both thermal and epithermal neutrons to overcome self shielding effects and subsequent misinterpreted assay results prevalent in the DDT method. The PIs are Kenneth Coop and Robert Estep of Los Alamos National Laboratory. 
In support of assay requirements prior to interim storage or treatment, the CTEN method employs ${ }^{4} \mathrm{He}$ detectors to expedite response and detection of fast fission neutrons in the presence of the epithermal interrogating flux, along with a redesign of the moderating cavity to ensure thermalization occurs more slowly. Once developed, a CTEN system could perform all the functions of existing DDT/passive-active neutron devices with the added capability of identifying and assaying lumps of material. This technology will be tested in the laboratory in FY 94.

\subsection{Radiological and Hazardous Material Measurement System-This}

technology was initiated in FY 92 to evaluate and enhance waste assay capability through improved individual measurement capability and integrating results from the multiple measurement cells of the system. Timothy J. Roney of INEL is the PI and will work in conjunction with Idaho State University (ISU).

Especially applicable to retrieve and treat options for buried waste, the RHMMS employs a passive gamma spectrometer to detect radiological decay of gamma nuclides, neutron interrogation for detection of fissile material, and capture gamma for monitoring hazardous material. Emphasis will be placed on expanding on individual measurement techniques performed at other laboratories and combining them with the RHMMS to provide a complete measurement system. Computer model development at ISU will be conducted during FY 94.

1.4.2.3.4 Assay of Contaminated Solls from Buried Waste Pits-This technology will be initiated and demonstrated in FY 94 as a passive gamma-ray spectroscopy system to assay excavated and treated waste material for TRU content. The PI is Timothy J. Roney of the INEL.

This technology will be used principally during pretreatment, posttreatment, and before disposal to confirm and quantify the presence of TRU wastes, to increase predictability and estimates of these wastes, and to ensure disposal requirements are met for clean stream output of treated wastes. The assay is conducted using a four subsystem setup employing: (a) a real-time radiograph to determine a actuation coefficient, (b) a high sensitivity gross count gamma scanner to determine gamma activity, (c) a high energy resolution gamma ray spectroscopy system to identify and quantify TRU, and (d) a neutron source activation of hazardous metal enables detection and quantification. This technology will be tested in FY 94.

\subsection{Active and Passive Computed Tomography Gamma Assay of}

Radioactive Waste-This technology, initiated in FY 93, will evaluate an active and passive computed tomography (A\&P CT) system on low-level radioactive waste and TRU waste contained in 55-gal drums. The PIs are David C. Camp and Harry E. Martz, Jr. of Lawrence Livermore National Laboratory with assistance from the University of California-San Francisco Bio-Imaging Research, Inc.

This technology will be used to support the assay requirements of retrieved packaged waste before interim storage or treatment and will concentrate measurements on fissile U-235 and Pu-239. The development of this technology will allow the ability to differentiate TRU from LLW; differentiate LLW from below regulatory concern (BRC) waste; to more easily meet transportation requirements; to increase assay effectiveness over gamma spectrometry methods; and decrease assay times. By implementing a high purity germanium (HPGe) detector, the system 
will make four primary determinations within the 55-gal drum: (a) spatial resolution, (b) energy resolution, (c) contrast sensitivity, and (d) total data acquisition time.

1.4.2.4 Office Research and Technical Review Meetings. No waste characterization technologies that do not involve field or laboratory efforts are funded in FY 94.

\subsubsection{Retrieval Technologies}

1.4.3.1 INEL Field Demonstrations. No field demonstrations of retrieval technologies are planned for FY 94 at the INEL.

1.4.3.2 INEL Laboratory Projects. BWID-funded projects of retrieval technologies that will be performed in INEL laboratories in FY 94 include as follows.

1.4.3.2.1 Cryogenic Cutting-The FY 94 demonstration of this technology will show how cryogenic methods may be applied to current waterjet techniques for cutting multiple material objects unearthed during buried waste retrieval operations without the introduction of the secondary waste-stream water. The PI is Dennis N. Bingham of the INEL.

The system will deliver a high-pressure liquid nitrogen and solid carbon dioxide fluid to perform cutting through a sophisticated nozzle. Advantages over current sizing and cutting technologies include no generation of a secondary waste stream, elimination of flame coincidental with plasma arc cutting tools, and no limitations because of size-reducing materials that are too large or too strong for the shears. This technology will be tested at the North Boulevard Robotics Complex in June 1994.

1.4.3.2.2 Cooperative Telerobotic Retrieval-The FY 94 demonstration of this technology will show the capability of dual acting robotic manipulators to perform selective retrieval of suspected problematic objects at a dig-face, particularly objects that are buried or potentially explosive, which would be more easily managed if processed separately.

Kevin M. Croft and Scott M. Allen of the INEL are the PIs and will be assisted by industry partners.

A delivery system will be used to transport and deploy the robotic manipulators in tandem activities to remove debris around the object and to retrieve it for subsequent treatment. In addition, a remotely-operated vacuum system will remove soil and debris and will be equipped with end effectors designed to break up hard soil and carefully clean around buried objects. A control system will be developed to coordinate activities, including required number of motions, the motion of the manipulators, and the operation of the vacuum system. This technology will be tested at the INEL's North Boulevard Robotics Center in FY 94.

1.4.3.2.3 System Health Monitoring-This technology, initiated in FY 93, involves developing a monitoring and prediction system for hydraulic, mechanical, and electrical failures of field demonstration equipment, particularly when equipment is housed in hazardous environments. Robert J. Macdonald of the INEL and Robert King of the Colorado School of Mines are the PIs. 
The purpose of the System Health Monitoring and Prediction Program (SHM\&P) is to test and develop a monitoring system capable of predicting equipment failure on remotely-operated equipment used in hazardous waste cleanup operations. During FY 94, bench-scale testing will be conducted at the INEL's North Boulevard Robotics Complex (NBRC) with the intention of (a) developing a bench scale test system for monitoring target equipment and collecting failure data from those tests, (b) to evaluate data from the failed components to assist in developing system health monitoring algorithms for failure prediction, (c) to discuss how these data can be deployed in a full-scale demonstration, and (d) to evaluate the system for future implementation by INEL Environmental Programs. This technology will be laboratory tested in FY 94.

1.4.3.3 Non-INEL Projects. Retrieval technologies whose efforts will be performed in facilities other than the INEL for FY 94 include as follows.

1.4.3.3.1 Full-Scale Remote Retrieva/-Initiated in FY 94, this technology will be used to demonstrate the use of a remotely-operated excavator for the retrieval of buried waste. John K. Rawlins of the INEL is the PI and will be assisted by Ed Brown from Wright Laboratory and Brad Richardson from ORNL.

To combat the inherent dangers of human exposure to hazardous environments, this remotely-operated technology is being developed with the intention of establishing baseline production rates by removing simulated waste contained in drums and boxes. The excavator operator will be housed onsite with a control system capable of controlling the excavator, readout of excavation information, and visual and audible information provided by cameras mounted on the excavator. Two-dimensional and three-dimensional images will aid the operator in performing several tests including dexterity, grasping small objects and cable, and handling large and difficult to maneuver objects without container breach. This technology will be demonstrated at Tyndall Air Force Base in FY 94.

1.4.3.3.2 Remote Excavation System-This technology was demonstrated at the INEL Cold Test Pit in FY 93. In FY 94, it will be applied to a specific class of buried waste remediation at Oak Ridge National Laboratory (ORNL). The Remote Excavation System (RES) is a teleoperated excavator used for remediation of buried waste and has an advanced control station that provides advantages over conventional excavation equipment including increased safety by removing workers from hazardous areas, lower costs by reducing the need for protective equipment, and increased operator efficiency. The PIs are Barry L. Burks, Stephen Killough, and David Thompson of ORNL.

The RES will be used at the Hill Cut Test Facility at ORNL with the intention of assessing operator exposure risks during overburden removal and cask handling. To handle the cormeta casks located there, a grappling end effector will be designed and integrated with the ex $\mathrm{S}$ and control station. The excavator is equipped with automated dig and dump functions, .....icipie video cameras, joint encoders, and other sensor feedback and sends data to the control station via radio frequency links or fiber optics. Remote technologies are most amenable to sites where high surface dose rate waste is present; the casks at ORNL represent an attractive test because the potential for contamination spread is minimal. 
1.4.3.3.3 Waste Conveyance for Buried Waste Retrieval-An automated conveyance system will be developed to allow transfer of retrieved waste from dig-face to processing and packaging area with minimal dust generation. The PIs are Phillip M. Rice and Ann Marie Smith of the INEL.

This technology is being developed to reduce the dust generation that results during retrieved waste conveyance, as well as to increase retrieval and transfer rates, and minimize personnel exposure through robotic means. The conveyance system, expected to involve an automatically guided vehicle (AGV), will be designed to be amenable to a variety of terrains and hazardous environments. This technology will be demonstrated at a vendor facility in July 1994.

1.4.3.3.4 Innovative End Effector-This technology will develop and demonstrate a system for dust free digging and dumping. The PIs are Guy G. Loomis, Phillip M. Rice, and Ann Marie Smith of the INEL.

The end effector will be designed to dig and transfer retrieved waste from the dig face to the waste conveyance system in an essentially dust-free environment. Target values for retrieval rate and dust generation have been set at $80 \mathrm{yd}^{3} /$ day and $2 \%$ of the dust load from a baseline set without dust suppression methods. This technology will be demonstrated in FY 94 at the vendor's facility. This technology will be demonstrated in July 1994 at a vendor facility.

1.4.3.4 Office Research and Technical Review Meetings. Retrieval technology projects that will require no field or laboratory work in FY 94 include as follows.

1.4.3.4.1 Three-Dimensional Simulation-This technology will focus on developing a comprehensive remediation system for Environmental Restoration and Waste Management (ER/WM) programs through modification of existing software packages to form three-dimensional images of several configuration options. Robert King of the Colorado School of Mines is acting as Principal Investigator.

Development of the graphical Three-Dimensional Dynamic Simulation Tool (3DDST) will produce a plan for retrieving buried waste (coupled with the BWID technologies) that can be integrated with baseline technologies to form a comprehensive remediation system. The 3DDST will meet this objective by defining the relative merits of proposed technical development activities of the BWID characterization/retrieval/ex situ treatment configuration option, by demonstrating cross-cutting technologies, and by providing communication on possible system scenarios to the BWID alliance of DOE laboratories, Federal agencies, and universities.

\subsection{Contaminated Material Excavation Handling and Retrieval}

System-Initiated in FY 94, this technology is an investigation of designing a movable, track-mounted containment system for emplacement over a waste site for retrieving waste. The PIs are J. Gary Carter and James Konyenbelt of Pacific Northwest Laboratory.

The Contaminated Material Excavation Handling and Retrieval System (CMEHRS) equipment is especially amenable to remediation and retrieval of localized hot spots. Equipment contained within the building would include blowers and a vacuum pickup system for contamination and dust control; several large overhead cranes for removing buried objects, a 
robotic arm for special handling; a drum venting station; a shielded work area for in-place glovebox analysis; and an airlock for entry and exit. Immediate application is foreseen at the Hanford site for cribs, trenches, and hotspots, and for repackaging TRU waste. This technology may be designed and fabricated in FY 95 and demonstrated for hot-spot retrieval in FY 96.

1.4.3.4.3 Hazardous Chemical Waste Separation at RWMC Excavation Sites-This task involves development of existing arms control technology to a level for use at remediation sites and dig faces. The technology will be used to screen for hazardous waste chemicals in cleanup activities. The FY 94 portion of this project is to cost out the system components purchased in FY 93. All of the components will be costed out in the first quarter of FY 94.

\subsubsection{Treatment Technologies}

1.4.4.1 INEL Field Demonstrations. No INEL field demonstrations of treatment technologies are planned for FY 94.

1.4.4.2 INEL Laboratory Projects. No treatment technology projects at INEL laboratories are funded by BWID for FY 94.

1.4.4.3 Non-INEL Demonstrations. Treatment technologies whose efforts will be performed at facilities other than the INEL include as follows.

1.4.4.3.1 Arc Melter Vitrification-This technology is continuing in FY 94 and development will be concentrated on further testing of the applicability of existing plasma arc melter technology for high temperature treatment of TRU and mixed hazardous wastes and buried or stored soils. Gary L. Anderson and Nick R. Soelberg of the INEL are the PIs.

The PIs will continue studies on treating waste containers and matrices containing organic and inorganic contaminated wastes and how they can be treated with an electric arc. Application of this technology is being conducted at a BOM three-phase arc melter furnace at the Albany Research Center, Oregon. After incineration in the 1.5 MVA, $1.5 \mathrm{ton} / \mathrm{hr}$ electric arc furnace, the resulting molten slag, upon cooling, produces a durable, vitrified cast form that may be safeiy disposed of. The arc melter process has been proven safe and can be modified for TRU surrogates and heavy metals containment. This technology will continue pilot-scale testing in FY 94.

1.4.4.3.2 Secondary Treatment of BWID Offgas using Nonthermal Plasma-This technology, initiated in FY 94, will investigate the capability of Nonthermal Plasma (NTP) to promote favorable chemistry for the destruction of volatile organic compounds (VOCs) and metal oxidation through nonincineration means. Louis Rosocha of Los Alamos National Laboratory and Peter Kong of the INEL are the PIs, with assistance from the Electric Power Research Institute and the University of Illinois.

The NTP process employs electrical energy in the process chemistry to produce highly reactive free radicals that oxidize or reduce pollutants, fragment pollutants, or promote excited-state chemistry. A high voltage is applied between the electrodes; thus creating a microdischarge on gases flowing between them. This energy is then channeled into free radical 
production. This technology can also be used for treatment of secondary waste gases from commonly used treatment processes for mixed waste, including vitrification, incineration, and thermal stripping. Research done in FY 94 will focus on lab-scale demonstration of organic and high vapor pressure metals (HVPMs) vapors, design-determination and scaling tests, and visualization of a prototype system. This technology will be laboratory tested in FY 94.

1.4.4.3.3 STRATEX for Treatment of Solls-This technology was initiated in FY 94 and will focus on development, evaluation, and demonstration of an integrated system, STRATEX, for processing and treating contaminated soil and other high-volume radioactive and hazardous wastes. The PIs are Robert Peters of Argonne National Laboratory and Leo V. Weitzman of LVW Associates.

STRATEX is an innovative alternative to conventional sequential treatment of thermally desorbed soil and solidification because it employs synergistic effects and overcomes heat transfer and turbulence problems by using special features and effectively performs both functions in one operation. STRATEX uses low-temperature heating from the reaction of the binder and steam mixed with the waste. Low particulate emissions are produced and water in the soil is chemically bound rather than boiled off. Use of condensable gas (steam) means the offgas stream is much smaller and easier to treat than a conventional desorber system. Laboratory testing is scheduled for FY 94.

1.4.4.3.4 Graphite DC Arc and In Situ Real-Time Measurements-This technology will continue in FY 94 with the objective of demonstrating and evaluating a graphite electrode, direct-current (DC) arc furnace for processing radioactive waste and mixed waste and soil and in implementing real-time measurement systems for in situ measurement and analysis of gaseous and particulate emission. The PIs are Jeffrey E. Surma of Pacific Northwest Laboratory, Dan R. Cohn of the Massachusetts Institute of Technology, and Charlie H. Titus of Electro-Pyrolysis, Inc.

Testing of the Mark II furnace will be done at a higher temperature than the previous Mark I tests and in a continuous processing mode. The furnace is equipped with electrodes that can be operated in a transferred or nontransferred mode and gives the furnace the ability to process at 1-MVA power giving up to a 1 ton/hr processing rate. The real time measurement systems include analytical equipment for measurement of furnace and glass temperatures and exhaust emission in the furnace chamber and offgas line. Furnace and glass temperatures will be analyzed, plasma sources will be tested for in situ measurement and analysis of gaseous and particulate emission in real time, and solid material composition will be analyzed at various stages of processing. Mark II testing will continue in FY 94.

1.4.4.4 Office Research and Technical Review Meetings. Treatment technologies that will require no field or laboratory work for FY 94 include as follows.

1.4.4.4.1 Modeling of Thermal Plasma Arc Technology-This technology will be initiated in FY 94 with the intention of developing a computer model of existing plasma arc treatment processes, specifically to determine distribution of slag and metal pool, efficiency in loading and minimization of metal offgassing, location of heavy metals, composition of waste slags, and effects of convection within the molten slag and melts. The PI is Michael G. McKellar of the INEL. 
The development of the computer model is vital in understanding migration of contaminants to the off-gas both by composition and into the equipment, to determine lower processing costs and better efficiency, and to model cause and effect scenarios of the physical processes occurring within the plasma arc facilities. Specific modeling tasks scheduled for FY 94 include:

(a) modifying the existing codes, (b) modifying the thermal analysis code, (c) modifying a chemical kinetics code, and (d) code integration and validation.

\subsubsection{Containment/Stabilization Technologies}

1.4.5.1 INEL Field Demonstrations. INEL field demonstrations of containment/stabilization technologies for FY 94 include as follows.

1.4.5.1.1 Innovative Grout Demonstration-In FY 94, this technology will demonstrate an innovative grouting concept for buried waste retrieval that encapsulates waste materials in a grouted block, which is retrieved by a remotely-operated bridge crane equipped with grapples, shears, and jackhammers. Guy G. Loomis of the INEL is the Principal Investigator.

The innovative grouting concept employs a three-step field demonstration process: (a) the waste is grouted using up to 8,000 psi pressure into the soil waste/matrix, causing an agglomeration of fine soil particles that may be contaminated; (b) the cured monolithic block is fractured using a demolition grout; and (c) the debris is excavated in a relatively dust-free environment using the bridge crane. Bench-scale experiments will be conducted in FY 94 at a vendor facility to address grout formulations prior to field demonstrations at the INEL Cold Test Pit in August 1994.

1.4.5.1.2 Monolithic Confinement-This technology is being developed to create a barrier beneath buried waste sites in basaltic field environments and to verify success by examining the inner granular regions for penetration of grout by bore-hole drilling. The PIs are Jerry Alexander and Steve Phillips of Westinghouse Hanford Company, with assistance from B. okhaven National Laboratory.

The barrier will be constructed by implementing a Casagrande drill apparatus to drill into basaltic formations and applying a jet grouting seal to fill the inner granular cracks in the basalt. This technology, if successful, would mitigate the migration of VOCs and other contaminants to groundwater aquifers below the basalt. A full demonstration of the technology will be conducted at the Bureau of Land Management's (BLMs) Box Canyon site in May 1994. A specially selected grout matrix will be applied to the basaltic test bed and chipped core samples will be analyzed following the grout application.

1.4.5.2 INEL Laboratory Projects. No containment/stabilization technology projects in INEL laboratories are funded for FY 94.

1.4.5.3 Non-INEL Projects. No non-INEL containment/stabilization technologies are funded for FY 94.

1.4.5.4 Office Research and Technical Review Meetings. No containment/stabilization studies that do not involve field or laboratory efforts are funded for FY 94. 


\section{ORGANIZATION AND RESPONSIBILITIES}

\subsection{Organization Chart}

The BWID organizational structure is given in Figure 1, and Figure 2 shows a chart of the BWID deployment team.

\subsection{Personnel Responsibilities}

\subsubsection{Project/Cost Account Manager}

The project/cost account manager (P/CAM) is responsible for ensuring project compliance with DOE and Management and Operation contractor requirements, DOE orders, and BWID directives. The P/CAM must develop and maintain the baseline for the project, ensure that the project meets cost, schedule, and scope objectives, as well as ensure all sponsored work maintains technical integrity. The P/CAM is responsible for providing weekly and monthly reports to BWID on the project.

\subsubsection{Integrated Demonstration Coordinator (IDC)}

The IDC functions as the focal point for all contacts and correspondence relative to BWID. The IDC is responsible for ensuring that the BWID programmatic objectives are achieved by recommending technologies and projects to the DOE-OTD through DOE- ID for inclusion in BWID and to support other Integrated Demonstration and Integrated Programs. The IDC oversees technology evaluations and programmatic direction with the assistance of the TSGs and TARGs. The IDC also functions as the principal interface with other OTD-sponsored Integrated Demonstrations or Integrated Programs.

\subsubsection{Technical Liaison}

The BWID technical liaisons (TLs) support the IDC. TLs ensure that the technical content of all BWID work satisfies the high-level objectives of the program and advances the technologies to state-of-the-art. TLs work with the PIs to ensure integration between BWID-sponsored projects, communicate closely with PIs to identify potential problems, formulate corrective actions, and serve as a member of a technology transfer team for commercialization/implementation of BWID-sponsored technologies.

\subsubsection{Deployment Coordinator (DC)}

The DC is responsible for sound project management practices and coordinating required activities for BWID-sponsored Technical Task Plans. The DC is responsible for monitoring technical progress, cost, and schedule performance of all participating organizations in accordance with established TTPs. The DC reports to the IDC on programmatic progress, makes recommendations affecting budgets and schedules, and suggests corrective actions as appropriate. The DC is responsible for assessment of project risk and contingency planning that identifies critical systems, subsystems, and other areas requiring focused analysis and resolution. Risks 


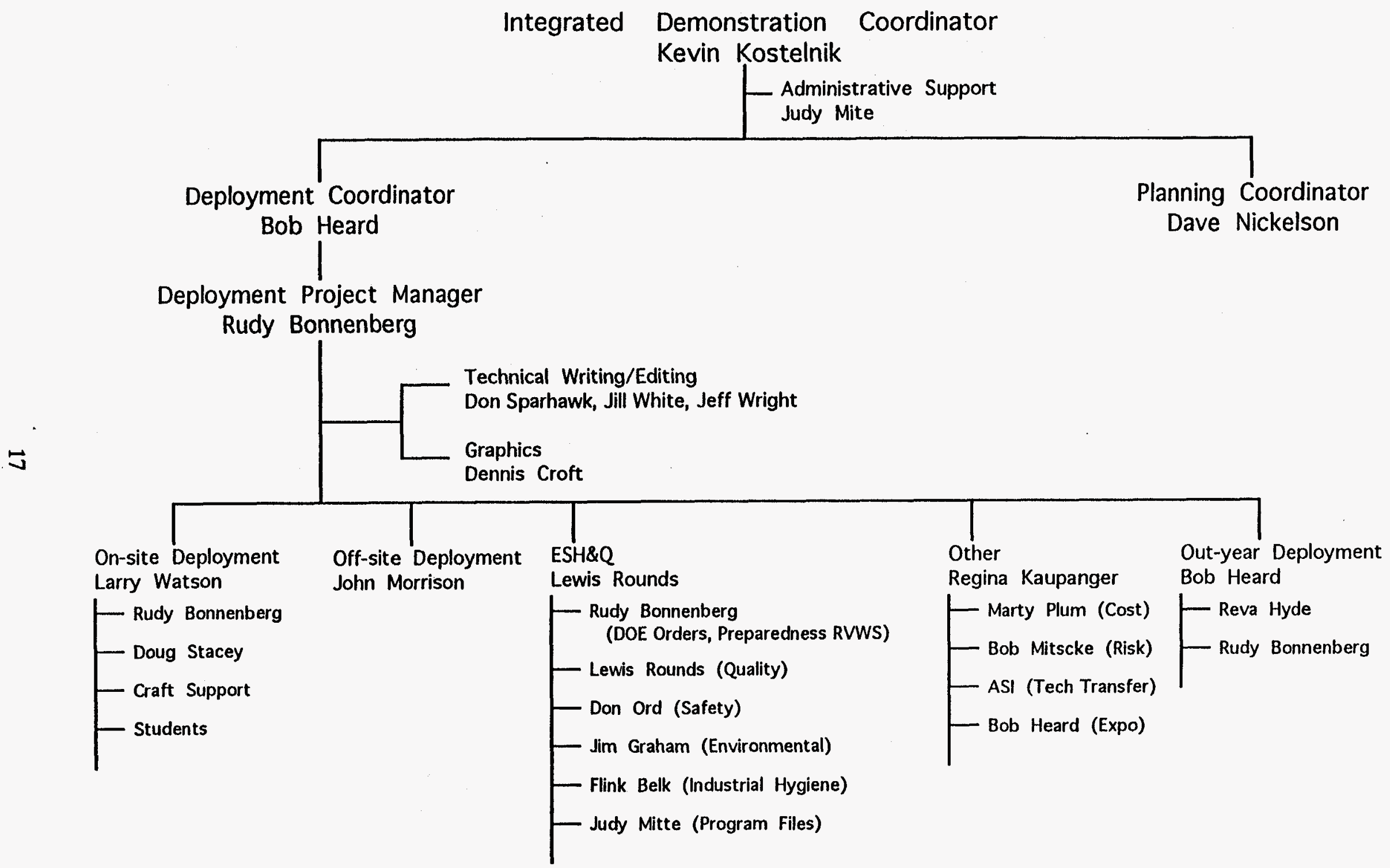

Figure 2. BWID defkyment team. 
appear in technical, schedule and cost, quality, environmental, health, safety, regulatory, and utility areas. It is the responsibility of the DC to ensure that authority is clearly delegated, and accountability for performance is established.

The Deployment Project Manager (PM) directly supports the DC to ensure that all tests are conducted in accordance with approved Test Plans and in compliance with all applicable regulations. The Deployment PM is the focal point for all participating organizations who demonstrate technologies under BWID. In FY 94, the DC is Bob Heard and the Deployment PM is Rudy Bonnenberg.

\subsubsection{Site Monitor}

During field testing, a designated BWID representative (site monitor) shall be present while equipment is operating. The site monitor has the responsibility to monitor, and, if necessary, shutdown operations. The site monitor shall observe all operations to ensure that the operations do not endanger the safety of any worker or the environment. The site monitor shall also receive copies of all data and logbooks and is responsible for ensuring that these data are properly transmitted to the BWID Office Database Manager to be scanned into the system. Site Monitors support the Deployment PM. During FY 94, site monitors for INEL tests will include Larry Watson, Rudy Bonnenberg, and Doug Stacey. The site monitor for INEL laboratory demonstrations will be Rudy Bonnenberg or a qualified delegate. For offsite tests, John Morrison is the site monitor. 


\section{ESH\&Q BWID Deployment Support}

\subsection{Description of BWID ESH\&Q Deployment Support}

BWID has recognized that facility, operational, and environmental, safety, health, and quality support will be required for successful demonstration and testing of the technologies. This section provides information describing the support requirements to ensure proper ESH\&Q oversight defined by the technology PIs and the BWID Deployment Team.

Each TTP, TP\&SR, Technology Preparedness Checklist and Action Plan, and Test Plan has been or will be reviewed by BWID personnel to identify operational support needs and issues. Resolution was and will be achieved through correspondence and discussions with the PIs. All issues raised as a result of the checklist review must be resolved, and the resolution approved by the BWID project manager before the demonstration can begin field operations. An approval to commence operations letter will be sent to the PI by the BWID Deployment PM.

Operational support needs, such as communications equipment, portable generators, etc., have been identified and will be provided as required (some subcontractors may prefer to provide their own equipment) by BWID. Operational support requirements are discussed in Section 4.

\subsection{Environmental Documentation}

The following sections discuss environmental compliance documents that are required for BWID projects. Areas addressed include National Environmental Policy Act (NEPA) Documentation, a Storm Waste Pollution Prevention Plan (SWPPP) for the CTP, Archeological Surveys, and Threatened and Endangered Species Surveys.

\subsubsection{National Environmental Policy Act Documentation}

Each TTP supported by BWID must have approved NEPA documentation prior to commencing with the activities. The PIs are responsible for completing Environmental Checklists (ECs) for their projects. BWID will ensure that proper NEPA approvals and conditions specified have been met before commencing with covered activities. Copies of all NEPA documentation will be kept in the BWID Program Files.

BWID has obtained NEPA approval for construction of the Cold Test Pit. Preparation of ECs for individual use of the CTP is the responsibility of the project PIs. Testing at the Box Canyon site (located on BLM land) also requires NEPA approval. The BLM developed an Environmental Assessment, ID-030-4-14, that was approved with several mitigation measures as was documented in a letter from Leroy Cook of the BLM to Ken Merrill on January 19, 1994. Although the Idaho Department of Water Resources has primacy for wells drilled at Box Canyon, state legislative requirements do not apply at the site in this case. The holes will be too shallow and the diameter too small to affect the geology above the water table. This information is documented in a Memo of Conversation between Dennis Duran and Larry Watson, dated 11/15/93. 


\subsubsection{Storm Water Pollution Prevention Plans}

A SWPPP is required for construction activities at the INEL. A SWPPP has been prepared and approved for activities at the CTP.

\subsubsection{Archeological Surveys}

Archeological surveys are required of U.S. government agencies before performing any activity that disturbs the ground. The survey checks the area for any archaeologically significant articles, and needs to be performed only once for an area. Archeological surveys have been performed for the CTP and Box Canyon site. These surveys are documented in the BWID project files.

\subsubsection{Threatened and Endangered Species Surveys}

Threatened and Endangered Species surveys have been performed for the construction of the CTP and use of the Box Canyon Site. These surveys are documented in the BWID project files.

\subsubsection{Clean Water Act}

If the Army Corp of Engineers determines that a Section 404 Permit under the Clean Water Act is required for the Box Canyon Site (due to drilling below the canyon rim), BWID will obtain the permit before drilling and provide a copy of this permit to the BLM.

\subsection{Hazard Classifications}

Hazard Classification determinations are required on all projects. The BWID Deployment Team supports projects in obtaining hazard classification determinations for each project by documenting the projects and obtaining Independent Safety Review Committee evaluations on those projects that require this level of review. Activities of the BWID Deployment team do not require hazard classifications separate from the demonstration projects.

\subsection{Technology Assessments}

Technology Assessments are performed by the Deployment Team for all field and laboratory tests. Technology assessments entail reviewing the project's equipment and instrumentation readiness for testing. Technology Assessment Reports (TARs) will be written within two weeks after the project review.

\subsection{Sampling and Data}

Sampling techniques and data collection procedures for each technology project are discussed in the individual test plans. However, the BWID Deployment Team will collect data on general events, deployment activities, and the environmental conditions at the Cold Test Pit. This is discussed further in Section 3.6.3, Logbooks. 


\subsection{Document Control}

\subsubsection{Data Management}

Each of the technologies being tested has their own data management system, however, BWID has a database that all data, logbooks, and reports must be scanned into from all the technologies (field tests, laboratory tests, and paper studies). The BWID Site Monitor and the PI are responsible for ensuring that all raw data and laboratory notebooks used during laboratory and field tests (on and offsite) are copied and supplied to the database manager within one week of completing the tests. Raw data should be in its original form (electronic or hard copy) whenever possible. A hard copy of electronic data shall also be supplied but may be delivered up to one month after testing. The technology Project Manager is responsible for ensuring that all other documentation is given to the database manager.

\subsubsection{Reports}

To ensure that the technologies, whether paper studies, laboratory tests, or field tests, provide useful data, the BWID Deployment Team has issued the following documents:

- Technology Preparedness and Status Report Guidance, EGG-WTD-10266, Rev. 1

- BWID Test Goals and Objectives, EGG-WTD-11112, Rev. 0

- Test Plan Guidance-EGG-WTD-9800, Rev. 1

- Technology Evaluation Report Guidance, EGG-WTD-10104, Rev. 2.

To ensure that the demonstration results are reported to interested parties, the following methods of data reporting will be used:

- Technology Evaluation Report-The data generated by the demonstration, as well as information on the planning and deployment of tests, will be assembled and documented in a Technology Evaluation Report. The Technology Evaluation Report will summarize the tests, test results and lessons learned, and will provide recommendations for further development. This is the responsibility of the technology PIs.

- Publications-Information on the demonstrations and results may be submitted by PIs for publication to the Waste Management ' 95 Conference and other waste management or environmental restoration related journals, conferences, and meetings. PIs shall inform BWID of such publications and presentations through the weekly reports to BWID.

- FY 94 Closeout Report-BWID Management team will produce a FY 94 Closeout Report that discusses the results of all of the projects. This report will be issued in FY 95. 


\subsubsection{Logbooks}

BWID will maintain a daily logbook for INEL field tests as an overall program record. The following information will be recorded in this logbook:

- Environmental conditions, including: temperature, approximate wind speed, precipitation

- Observations of technology integration problems and their resolutions

- Lessons learned

- Incidence and disposition of any injuries or accidents occurring at the CTP

A separate record will be maintained listing all personnel and visitors present at the CTP. A logbook of laboratory testing at the INEL will also be maintained by BWID with the same information, where applicable.

\subsection{Quality Assurance}

All BWID projects must have a documented quality program that addresses the basic elements identified in the American National Standards Institute/American Society of Mechanical Engineers Nuclear Quality Assurance standard, (ANSL/ASME) NQA-1. For projects to be completed at the INEL and at Box Canyon, the quality program will follow the EG\&G Idaho Quality Assurance Manual and the Office of Waste Technology Development Quality Program Plan-044 (QPP-044). Projects continuing on from previous years may use QPP-337 if it was originally designated. Both QPP-044 and QPP-337 include the requirements of NQA-1.

BWID projects demonstrated at other DOE facilities must comply with quality programs in effect at their locations. For projects being performed at other than a DOE facility, the quality program needs (NQA-1 basic requirements and supplements) must be addressed with the subcontract.

Data quality objectives (DQOs) shall be identified and addressed in a DQO document, test plan, or work release document as agreed to by the BWID project manager. BWID has provided test plan guidance to PIs in the Buried Waste Integrated Demonstration Program Technology Test Plan Guidance. ${ }^{1}$ Test plans will be reviewed for quality requirements by the BWID Deployment Team.

\subsubsection{Internal Quality Control Checks}

Internal quality control checks will be performed during and after testing. These include reviewing completeness and accuracy of the logbooks, executing performance and system audits, and checking to ensure that the established procedures are being followed. 


\subsubsection{Performance and System Audits}

Performance audits are conducted to quantitatively and qualitatively evaluate the outputs of a measurements system. System audits are conducted to qualitatively evaluate the operational details of a quality assurance (QA) program. These audits will be conducted internally by the BWID Deployment QA support member.

A system audit to verify that the instrument(s) are operating within expected parameters will be done before and after the INEL demonstration by the respective operations personnel. This information will be documented in the PI's logbook.

\subsection{Health and Safety}

\subsubsection{Safety Reviews and Checks}

The BWID safety engineer shall conduct a safety walkdown of the CTP area weekly when field demonstrations are being performed. The Safety Engineer (and any other involved person) has the authority to stop work if he considers it necessary. Safety discrepancies and concerns shall be reported to the BWID Deployment PM. Corrections will be funded and completed by BWID or by the demonstration PI, depending upon the nature of the identified problem. At the Box Canyon site, the onsite monitor is responsible for performing safety walkdowns.

BWID and subcontractor personnel are responsible for complying with the applicable sections of EG\&G Idaho, Inc., Safety Manual, ${ }^{2}$ EG\&G Idaho Industrial Hygiene Manual, ${ }^{3}$ RWMC Operational Safety Requirements Safety Analysis Report, ${ }^{4}$ EG\&G Idaho Conduct of Operations Manual, ${ }^{5}$ and Environmental Restoration Program Generic Health and Safety Plan. ${ }^{6}$ If required, safety-related training is available from centralized safety training at the Central Facilities Area (CFA).

\subsubsection{Safe Work Permits}

All work performed at the INEL must be reviewed and approved by a Facility Health and Safety Representative and documented in Safe Work Permits, as required. All work will be performed in compliance with all of the health and safety requirements for the BWID project as identified in the BWID PMP.

\subsection{Residuals Management and Waste Minimization}

Procedures for disposal of solid wastes are contained in the EG\&G Idaho Company Procedures Manual, Section 8.12, "Solid Sanitary Waste Segregation and Recycling Procedures for Using the INEL Landfill. ${ }^{7}$ BWID will have three dumpsters placed at the CTP to receive metal, wood, and other refuse (e.g., office paper). Waste Disposal is described further in Section 4.1.7.

Secondary wastes from laboratory and field tests are the responsibility of the PI of each technology. The BWID Deployment Team will support the removal and ultimate disposal of secondary waste streams if requested by the PIs. In addition, if a secondary waste stream from 
one technology could be used as a resource on another project, the BWID Deployment Team will identify this and coordinate transfer of the waste/resource. For example, the Innovative End Effector and Waste Conveyance technologies will have retrieved simulated buried waste as a secondary waste stream. The BWID Deployment Team has determined that this can be a resource for some of the Treatment technologies. Therefore, instead of sending this simulated waste to the landfill, it will be boxed and sent to vendors participating in the treatment technology demonstrations or will remain at the CTP in boxes or with some other storage method. Disposal of secondary wastes and other test residuals are the responsibility of the project PI. 


\section{DEPLOYMENT PLAN}

For the purpose of defining deployment needs, the BWID-sponsored technologies are divided into INEL field demonstrations, INEL laboratory tests, non-INEL demonstrations, and paper studies.

\subsection{INEL Field Demonstrations}

FY 94, field demonstrations will take place at the INEL Cold Test Pit, and the Box Canyon Site. Projects to be demonstrated at the INEL Cold Test Pit include: Very Early Time Domain EM (VETEM), Innovative Grout Demonstration, BWID Dig-face Characterization, and NonIntrusive Sensing of Environmentally Important Objects. The deployment needs of these four technologies and the Monolithic Confinement Demonstration at the Box Canyon Site, are discussed in this section. The field demonstration performed at the INEL are shown in Figure 3.

\subsubsection{Facilities}

4.1.1.1 Test Area Preparation. Predemonstration site preparation includes the following activities:

- Coordinating the development of new CTP cells.

- Filling and grading at the Cold Test Pit and Box Canyon, as necessary, in order to prepare surfaces for trailer locations and for tests.

- Installation of BWID signs for safety, security, and other important information at the Cold Test Pit, Box Canyon, and the RWMC, as required.

- Installation of the administrative support trailer and supplies.

- Addition of gravel layer at Box Canyon. BWID has covered lithic scatter that has been identified at Box Canyon with several inches of gravel and will ensure that no disturbance occurs in the covered area from testing activities.

- Arrangement for video/photographic services.

4.1.1.2 Interface Agreement with RWMC. An interface agreement has been prepared and approved by the BWID deployment PM and the RWMC building manager. This document defines roles and responsibilities for the BWID and RWMC at the CTP. The interface agreement should be reviewed by all PIs demonstrating at the CTP.

4.1.1.3 Access and Security. Access and security issues at the Cold Test Pit are discussed in the RWMC interface agreement. Adherence to the requirements is the responsibility of the PIs testing at the Cold Test Pit. 

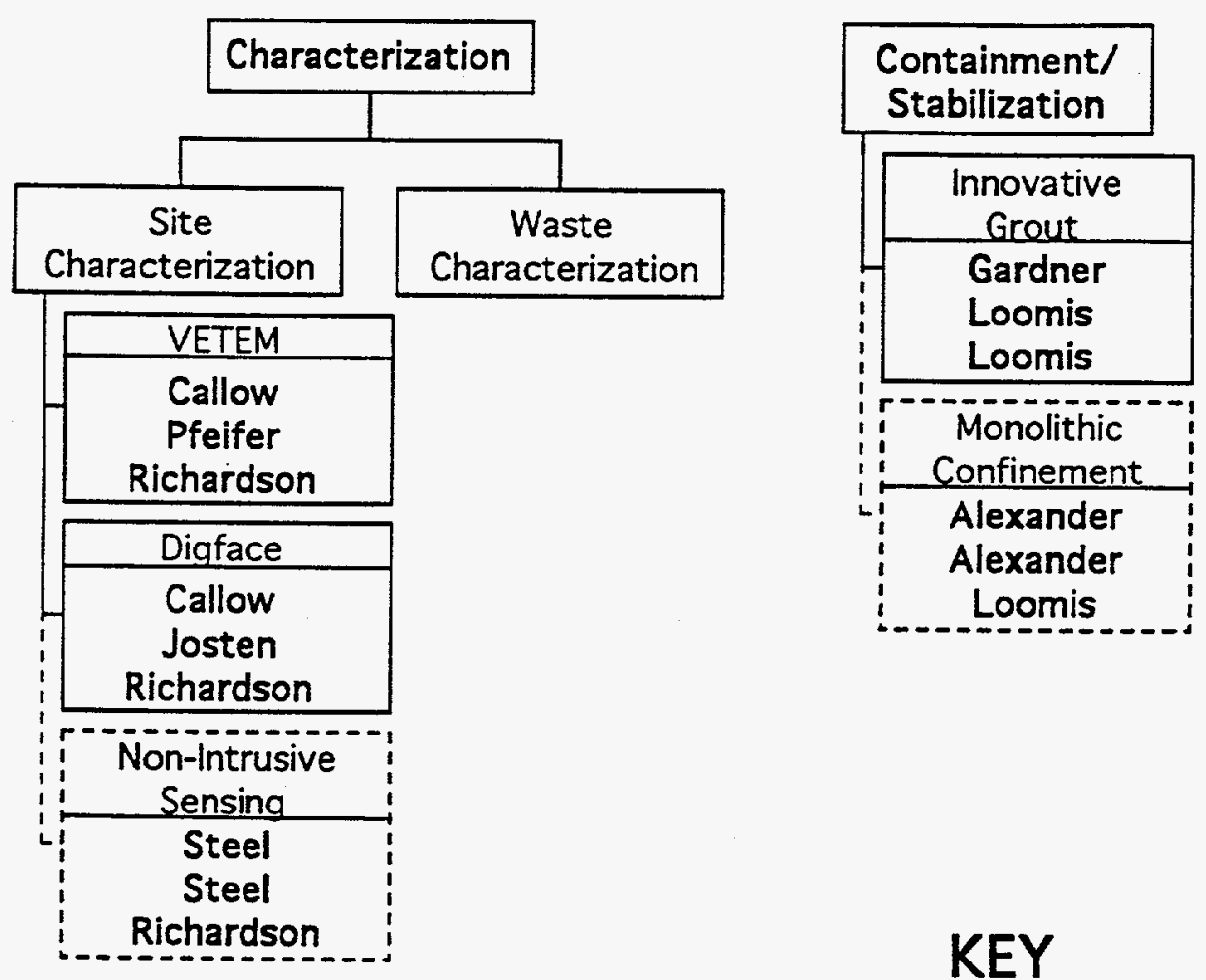

KEY

Project/Cost Account Manager

Principal Investigator

Technical Liaison

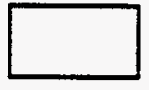

INEL TTP

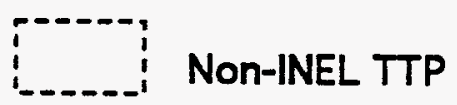

TTP Title

P/CAM

PI

TL

Figure 3. Field demonstrations performed at the INEL. 
BWID is responsible for arranging for security surveillance within the CTP area. The RWMC shall modify the requirements of the roving watch to include a visual check of the CTP from inside the RWMC compound during normal rounds.

Located on BLM land, there are no INEL access or security requirements at the Box Canyon Site. All equipment should be secured and protected to the extent possible by BWID and demonstration personnel.

4.1.1.4 BWID Administrative Support Trailers. BWID will provide one $10 \times 24-\mathrm{ft}$ travel trailer to be used as an administrative support facilities at the Cold Test Pit. The trailer will be equipped with a smoke detector and two fire extinguishers. Westinghouse Hanford personnel will provide their own administrative support trailer for the Box Canyon Site.

There is no running water or liquid drains at either facility. Bottled water will be supplied by BWID.

At the CTP and the Box Canyon Site, communications will be maintained with the RWMC and town facilities by radio and cellular phones. At the CTP, two personal computers and a printer will be available for BWID and demonstration personnel use. BWID will provide IBM WordPerfect 5.1 software. Other hardware and software will be the responsibility of demonstration personnel.

4.1.1.5 Sanitary Facilities. BWID will supply portable toilets at the Cold Test Pit and at Box Canyon. There is no running water or liquid drains at either site. Sanitary facilities are also available inside the gate of the RWMC.

4.1.1.6 Equipment, Instruments, and Supplies. BWID will supply and maintain the following supplies for field tests:

- Safety equipment, including first aid kits, chemical dosimeters, fire extinguishers, and fire alarms

- All necessary signs for safety, traffic, information, etc.

- Waste receptacles for non-hazardous and non-radioactive waste

- General hand tools

- Personnel Protective Equipment (PPE), including hard hats, safety glasses, gloves, and an eye wash station (at the Cold Test Pit)

- A weather station at the Cold Test Pit, supported by the National Oceanic and Atmospheric Association (NOAA). This station will provide the following information for any test requiring weather information: wind speed, wind direction, temperature, humidity, and barometric pressure. 
The following services will be supplied for field tests:

- Coordination of receipt of equipment at site

- Site orientation and demonstration site training

- The escort of visitors to site when necessary

- Use of mobile phones

- Fuel and water delivery. BWID will coordinate the delivery of fuel and water to the field demonstrations. However, each project is responsible for the cost of their share of this service. If fuel is required at Box Canyon, a geotextile liner will be installed below the tank. A berm will also be installed around the tank. Both the liner and the berm will be removed at the completion of operations. BWID Deployment will coordinate these activities, if requested, but the Monolithic Confinement project is responsible for the cost.

At all facilities, equipment will be locked up at night and on days they will not be required. Protective measures will be taken to ensure that the equipment is not damaged during shipping to and from the INEL.

4.1.1.7 Crafts Support. BWID and BWID-funded demonstrations are responsible for budgeting, funding, and conducting maintenance and repair of all equipment, real property, and site restoration activities within the demonstration boundaries. Because BWID is solely responsible for all crafts activities within the demonstration area boundaries, the Radioactive Waste Management Complex Tenants Manual ${ }^{8}$ is not applicable to BWID activities conducted at the Cold Test Pit. However, all work performed by RWMC personnel is controlled, scheduled, and performed in accordance with existing, approved, and controlled procedures. In addition, if BWID contracts for RWMC capabilities, BWID is bound by the Radioactive Waste Management Complex Tenants Manual and project directives as they apply to the contracted service.

\subsubsection{Utilities}

4.1.2.1 Electricity. Electrical power for field demonstrations and trailer lighting will be provided by portable electric generators. PIs must contact BWID as soon as possible to identify their electrical requirements.

4.1.2.2 Water. Water is available from a well and can be supplied to the Cold Test Pit and Box Canyon with a water truck from the RWMC or CFA. Water will be supplied by BWID operations support in case of fire and possibly for additional dust suppression. Drinking water will be available at the trailers.

\subsubsection{Transportation}

The CTP is located adjacent to the RWMC, approximately 52 miles from Idaho Falls. State Highway 20 passes between the RWMC and CFA. Bus service is available for INEL personnel 
Monday through Friday to CFA and Monday through Thursday to RWMC. The buses leave and return to CFA and Idaho Falls on regularly scheduled routes. Generally, INEL personnel will drive personal or INEL motor pool vehicles, and subcontractor personnel will drive personal or subcontractor vehicles to the CTP.

The Box Canyon site is located near the western boundary of the INEL, 12 miles west of the RWMC turnoff on State Highway 20. INEL buses do not travel to the Box Canyon Site. All personnel will be responsible for their own transportation to the area.

\subsubsection{Site Restoration}

It is the responsibility of the PI of each demonstrated technology to remove all of their equipment and associated items from the test areas and restore the site to pretest conditions. BWID may request that the CTP be returned to other than the pretest conditions and will negotiate the final pit condition prior to the technology entering the field.

4.1.4.1 Revegetation. Revegetation of the CTP demonstration site may or may not be necessary. This determination will be made by the BWID project manager.

At Box Canyon, the PI will ensure that all disturbed areas where soil material exists will be reseeded with the following seed mix:

Indian Ricegrass, Nezppar 6 lbs/acre

Crested Wheatgrass, Ephriam 5 lbs/acre

BWID will be responsible to inspect the disturbed area on a yearly basis and spray noxious weeds that invade the area. This inspection and spraying will continue until the revegetation is completed to the satisfaction of the BLM.

4.1.4.2 Additive Substances. Substances that may be added to, in, or on the soil may or may not need to be removed. The determination will be made by the BWID project manager. Written approval of the BWID project manager is mandatory before deployment of technologies requiring such additives. Technology demonstrations wishing to consider the long-term remedial or environmental effects of such additives may leave the additives in place with the written consent of the BWID project manager. Descriptions, amounts, and the locations of additives shall be supplied to BWID by the PI and added to the BWID program file for the CTP.

Once the Monolithic Confinement proiect is completed, all drill casing will be cut off at the surface, and all non-grouted holes will be finsed to the surface or plugged with $3 \mathrm{ft}$ of cement at the surface to meet Army Corp of Engineers requirements.

4.1.4.3 Excess or Discarded Materials and Equipment. All construction material, lumber, excess or discarded equipment and supplies, either used or unused, must be removed from the site at the conclusion of the demonstration. Material relevant to long-term monitoring may be left with the written approval of the BWID project manager. Other discarded material is 
addressed in Section 3.9, Residuals Management and Waste Minimization. Some materials may require sizing to facilitate disposal; this will be an additional cost to the demonstration project.

The PI of the Monolithic Confinement Project is responsible for cleaning up excessive grout around the injection holes at the Box Canyon Site. In the event grout flows or blows into the site, the PI will be responsible for removing the grout from the canyon or diluting the grout with water. The BWID Deployment team will aid in these activities as needed.

\subsubsection{Medical and Emergency Plans}

4.1.5.1 Emergency Response Plan. The Emergency Response Plan for BWID activities at the Cold Test Pit is discussed in the BWID/RWMC Interface Agreement. In case of an emergency at the Box Canyon Site, the Emergency Brigade at CFA shall be contacted. Emergencies will be communicated via land-based radio-F net, which is monitored by the INEL Warning Communications Center (WCC).

4.1.5.2 Spill Plan. The RWMC Spill Prevention Control and Countermeasures (SPCC) Plan will be used at the Cold Test Pit and the RWMC. The SPCC Plan can be found in the RWMC Emergency Plan/RCRA Contingency Plan. ${ }^{10}$ The Monolithic Confinement Project will define a Spill Plan for the Box Canyon Site.

4.1.5.3 Medical Plan. First aid kits are located within the BWID administrative support trailers and RWMC guard gate. First aid certified personnel are assigned to the RWMC. A first aid certified person from the project or from BWID will also be at the Box Canyon demonstration. In addition, medical personnel, services, and facilities are located at the CFA, approximately 7 miles from the Cold Test Pit and approximately 20 miles from Box Canyon.

\subsubsection{Training}

4.1.6.1 Training Responsibilities and Requirements. BWID has established training requirements and training responsibilities for BWID and BWID subcontractor personnel. Minimum requirements, training quality, and general guidance are defined in Training Requirements and Responsibilities for the Buried Waste Integrated Demonstration at the Radioactive Waste Management Complex. 9 The report contains a personnel training matrix that specifies training to satisfy Federal requirements. Guidance for the PIs for FY 94 is also given in ProjectSpecific Training Requirements and Responsibilities for the Buried Waste Integrated Demonstration at the Cold Test Pit and Box Canyon Site. This document provides specific training requirements for each field project. A thorough review of these documents should be undertaken by the PIs early in the demonstration planning process.

The BWID deployment team and the demonstration PI are responsible for scheduling and coordinating training well before it is needed to avoid unnecessary demonstration delays. Individual project funds will bear the costs of any required training for project and subcontractor personnel. BWID will bear the costs for required training of BWID personnel. Adequacy and appropriateness of the training will be confirmed by the trainer and BWID project manager. 
4.1.6.2 Demonstration Specific Training. PIs are responsible for ensuring that all project personnel receive the training applicable to their specific demonstration.

\subsubsection{Waste Disposal}

BWID will have three dumpsters placed at the Cold Test Pit to receive metal, wood, and other refuse (e.g., office paper). Demonstration personnel are responsible for separation of their wastes to facilitate recycling. Disposal of any hazardous or otherwise controlled wastes are the responsibility of the PI and the PM. BWID will assist with disposal, if requested.

All drilling debris and other trash from testing at Box Canyon will be disposed at the Butte County landfill. If any type of drilling fluids need to be used, they will be properly disposed to preclude entry into surface waters.

\subsection{INEL Laboratory Demonstrations}

The FY 94 laboratory demonstrations performed at the INEL are shown in Figure 4.

\subsubsection{Facilities}

Seven laboratory- or bench-scale tests will be conducted in INEL laboratories. PIs must work within the landlord/tenant agreements for each INEL facility [e.g., Test Reactor Area (TRA), North Boulevard Robotics Center (NBRC), and Test Area North (TAN)] and must comply with all access, security, safety, emergency plan, spill control plan, and other requirements of those facilities.

The PIs are responsible for identifying and following all facility specific requirements. They are also responsible for training any personnel involved in the demonstration. This includes access orientation training, facility specific training, and demonstration specific training.

\subsubsection{Crafts Support}

PIs may require general laborers, heavy equipment operators, electricians, or other support personnel from the INEL crafts organization during testing and/or the BWID equipment expo. BWID will be the central contact for RWMC and CFA labor used in BWID demonstrations. PIs should contact the BWID deployment team as soon as possible to arrange for this support.

\subsection{Non-INEL Demonstrations}

There are sixteen demonstrations to be performed in FY 94 at the locations other than the INEL. These technologies are shown in Figure 5.

\subsubsection{Facilities}

These demonstrations will take place at non-INEL locations, including subcontractor sites, universities, and other DOE facilities. In all cases, PIs must comply with the facility regulations, 

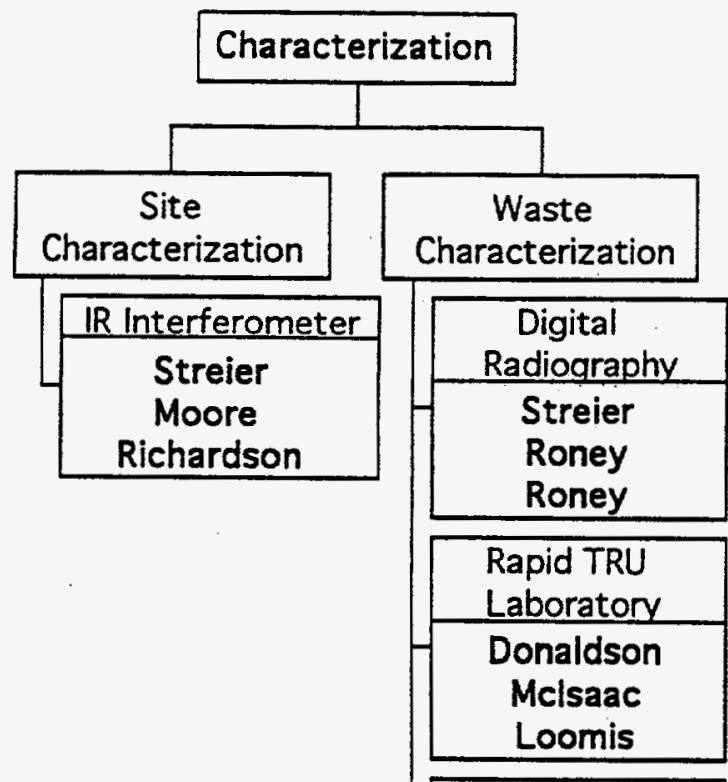

TRU Dust

Donaldson

Fincke

Loomis
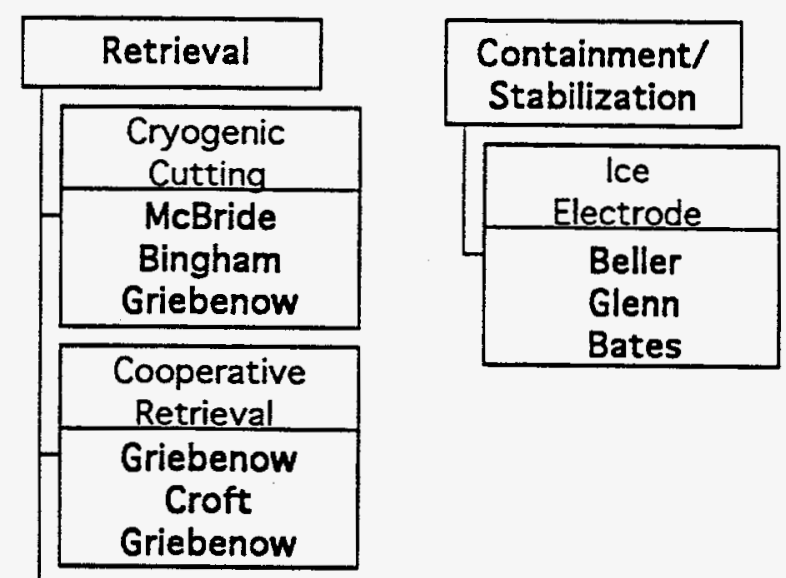

\section{KEY}

3

Project/Cost Account Manager

Principal Investigator

Technical Liaison

INEL TTP

Non-INEL TTP

TTP Title

P/CAM

$\mathrm{PI}$

TL

Figure 4. Laboratory tests performed at the INEL. 


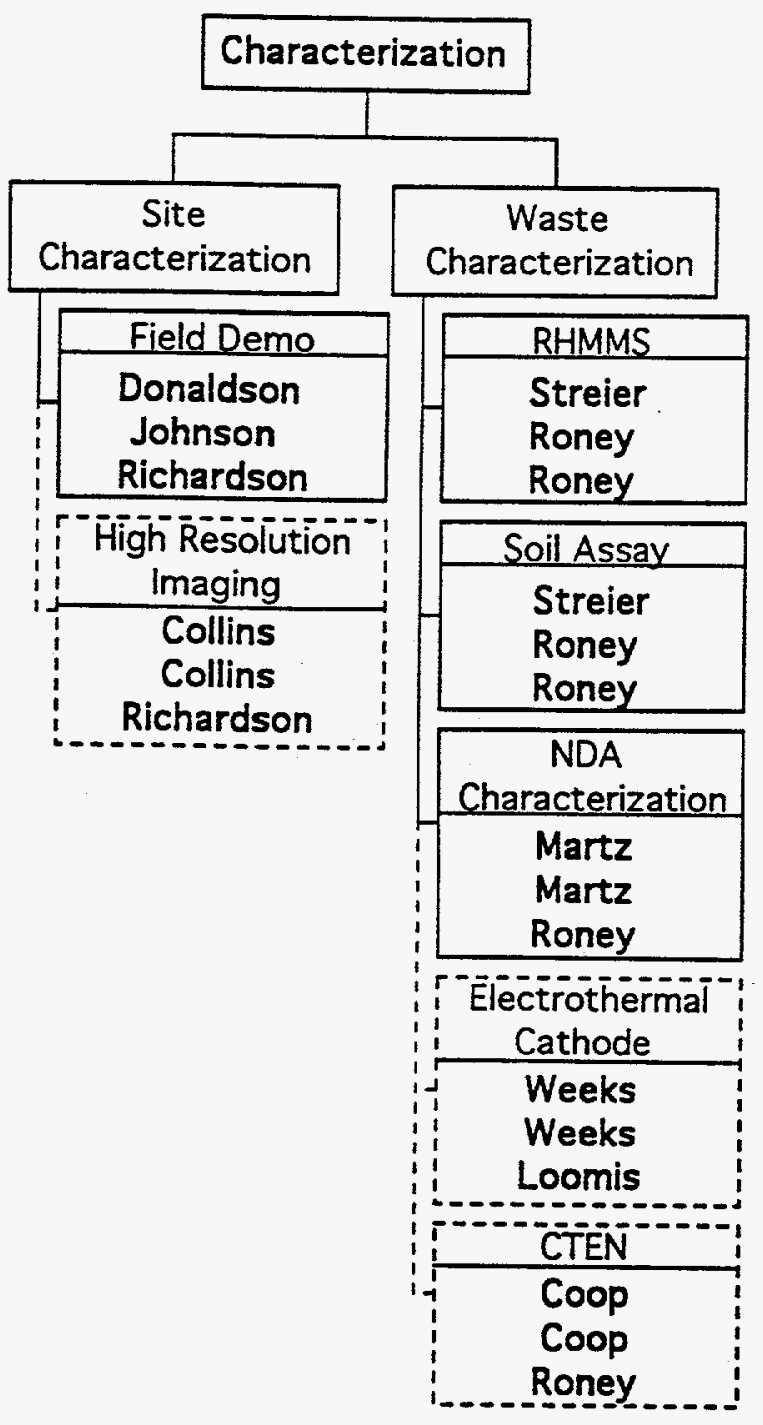

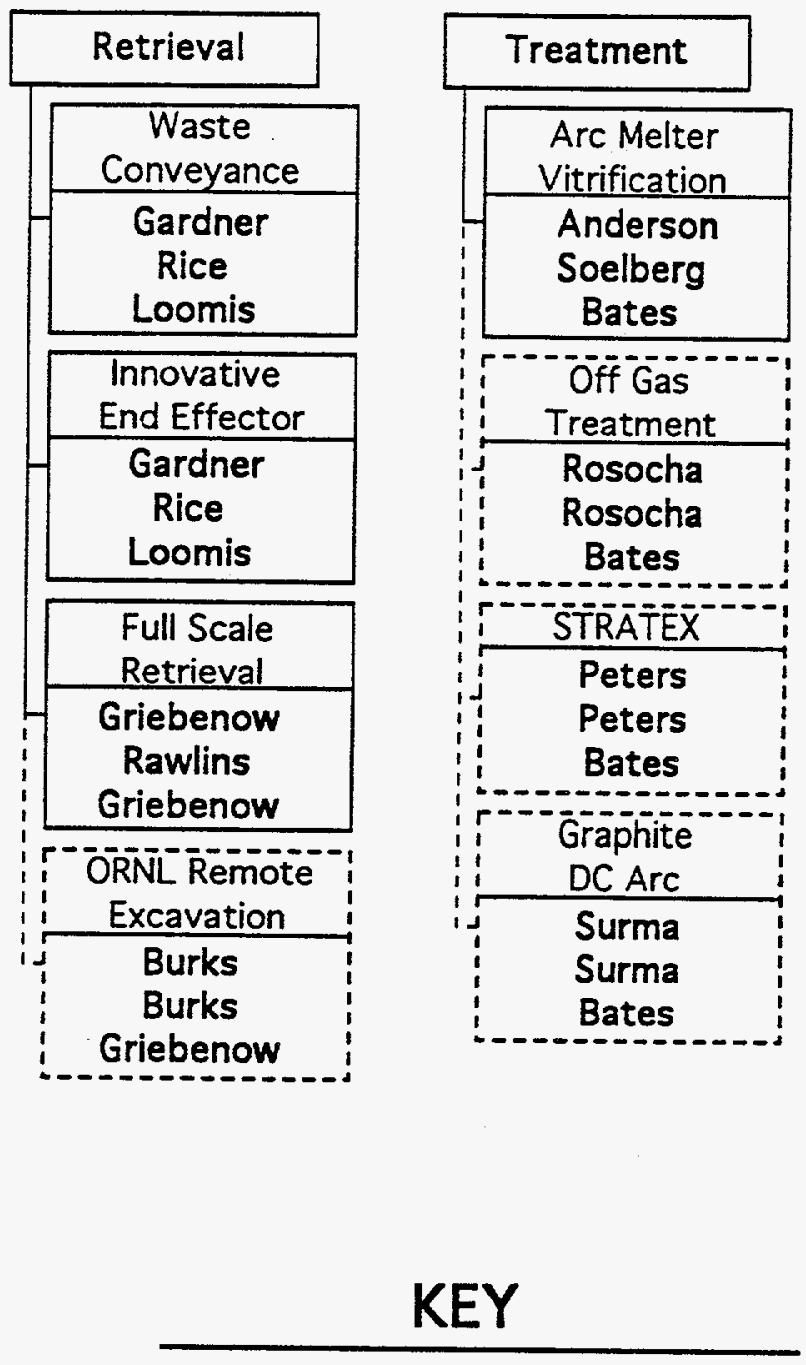

Project/Cost Account Manager

Principal Investigator

Technical Liaison

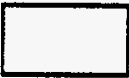

INEL TTP

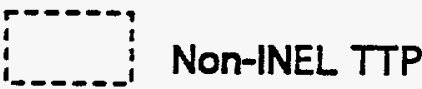

TTP Title

P/CAM

PI

TL

Figure 5. Non-INEL demonstrations. 
landlord/tenant interface agreements, and security and safety regulations of the facility in which the work is performed. PIs must also ensure compliance with all applicable DOE orders. PIs should consult with BWID Deployment Team personnel to resolve any issues or concerns.

The subcontractor is responsible for communications, utilities, and other services required to perform the demonstration. BWID will provide managerial review of the work and technical guidance during all phases of the project and will witness the field demonstration. No materials or other services will be provided by BWID.

The subcontractor is also responsible for emergency medical and fire response, safety oversight, and training.

\subsection{Office Research}

The nine remaining BWID-sponsored projects include office research (paper studies and computer simulations) and technical review meetings. PIs are responsible for following all requirements for training, emergency response, waste disposal, etc., defined for the facility in which the work is performed. No deployment support needs are expected. These studies are shown in Figure 6. 

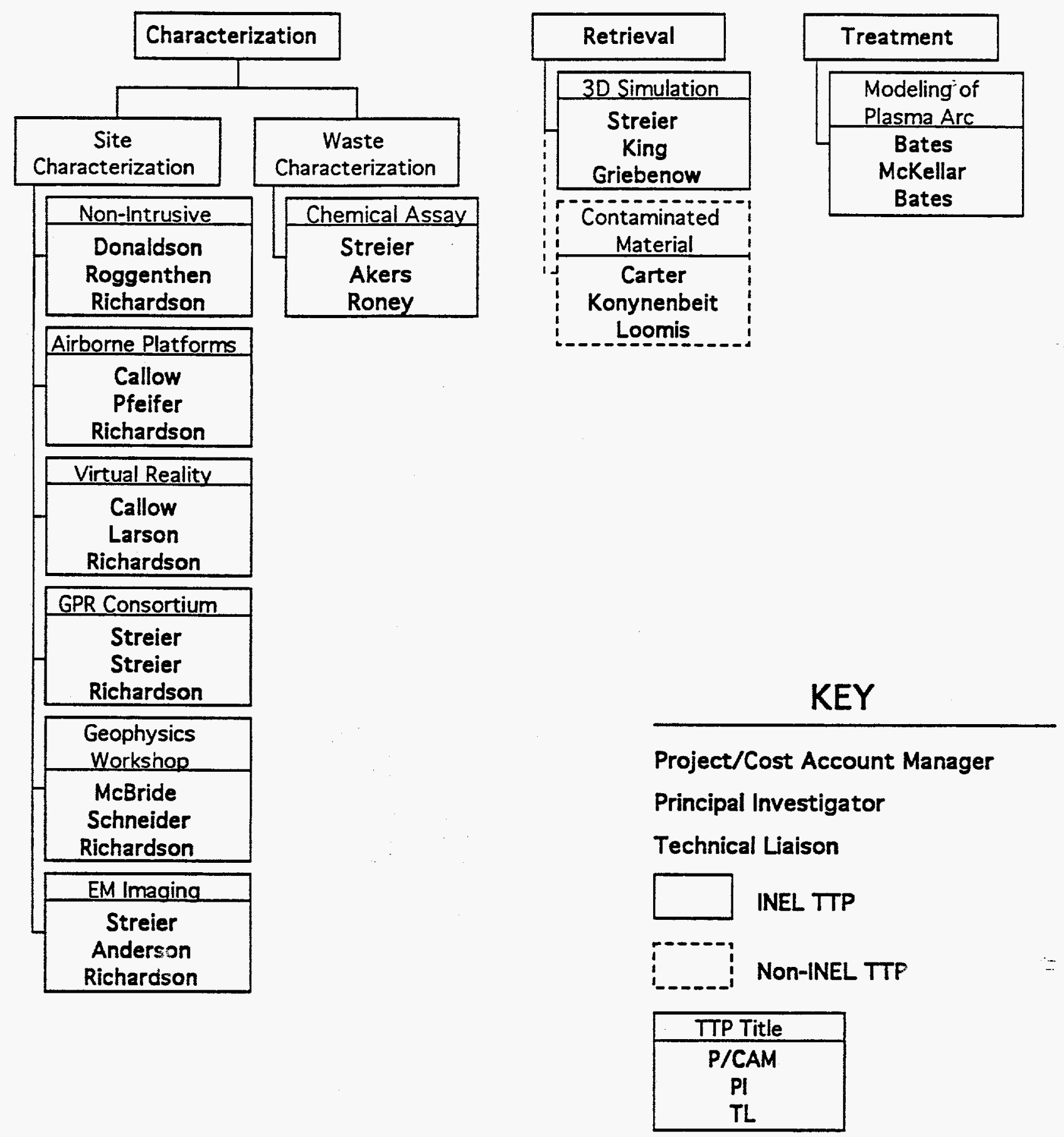

Figure 6. Office research. 


\section{PUBLIC OUTREACH}

BWID has established a public outreach strategy to educate the general public, elected representatives, and regulatory agencies about waste technology demonstrations. Presentations, media releases, interviews with media representatives, an open house, and an equipment display, are among the mechanisms used in the outreach strategy.

\subsection{Media Releases}

During INEL demonstrations, BWID personnel will work with PIs to prepare media releases for the INEL Public Affairs Office. As appropriate, media tours may be organized. Any visits to the test sites during demonstrations will be coordinated with the PIs and will be designed to minimize or prevent impact on the demonstration. As results of the demonstrations become known, follow up media releases will be prepared by BWID and the PI. Interviews between BWID or demonstration personnel and media representatives may also be arranged through BWID and the INEL Public Affairs Office.

\subsection{Photographs and Video Records}

The BWID Deployment Manager will arrange for photographic and video coverage of the demonstrations. PIs must contact the BWID Deployment Manager at least 6 weeks prior to the demonstration for photography/video support. Photographic/video coverage, while not required by $\mathrm{BWID}$, is strongly recommended to provide useful historical information for presentations, papers, and poster sessions about the technology, as well as for the Technology Development File. INEL photography will provide professional photographers for this task. Arrangements must be made well in advance to avoid schedule conflicts.

\subsection{Open House and Equipment Display}

An open house and equipment display is scheduled for the week of August 8, 1994. Representatives from DOE Headquarters (DOE-HQ), DOE Idaho (DOE-ID) Operations Office, private industry, local government, the media, DOE Program Planning and Technical Support Groups, and ID and IP coordinators will be invited to attend.

BWID will organize and mail invitations to the open house. PIs will be responsible for preparing a poster session and video presentation. Information may include a description of the technology, demonstration objectives, technology need, baseline technologies, demonstration results, and follow-on activities.

The equipment display will feature the equipment used for technology demonstrations. PIs will be responsible for transporting and setting up the equipment at University Place in Idaho Falls. PIs will also be responsible for providing personnel to explain technology and equipment features to attendees. BWID will provide equipment security by Protection Technology Idaho through EG\&G Idaho Physical Security. 


\subsection{Midyear Review}

The OTD will conduct a midyear review of technologies in March 1994, in Washington D.C. The BWID midyear review is in February 1994 in Denver, Colorado. 


\section{SCHEDULES}

In this section, schedules are provided for the BWID Deployment team activities, field tests, laboratory tests, and non-INEL tests. Paper studies are not addressed because all final reports will be submitted on or before September 30, 1994.

\subsection{BWID Deployment Team Activities Schedule}

Figure 7 shows the schedule for activities the deployment team is performing to support the technology demonstrations, tests, and evaluations. The schedule includes preparation activities such as obtaining and deploying generators, toilets, fire extinguishers, PPE, etc. In addition, the schedule shows pit construction and site restoration activities. It should be noted that the schedule also shows activities that are ongoing. For example, preparedness reviews are conducted for each project prior to field testing. Because these preparedness reviews are not held at the same time, a single schedule line is included spanning the range of reviews currently planned. Table 1 shows the deployment team schedule for technology assessments and preparedness reviews. Table 2 shows the deployment team schedule for guidance and ESH\&Q plans.

\subsection{Field Test Schedule}

Figures 8 and 9 show the field test schedule and the detailed CTP schedule. Box Canyon and Cold Test Pit activities are shown in Figure 8. Cell construction is also included on this schedule because technology testing would be affected during this period. Figure 9 shows more detail on activities at the CTP.

\subsection{Laboratory Test Schedule}

Figure 10 shows the laboratory test schedule. Project testing will occur at the NBRC. Each of these locations are shown by different line types.

\subsection{Non-INEL Test Schedule}

Figure 11 shows the schedule for non-INEL tests. Project tests will occur at LANL. Each of these locations is shown by a different line type. To distinguish between laboratory and field tests, after the project title, a $-\mathrm{L}$ or $-\mathrm{F}$ is shown. 


\begin{tabular}{|c|c|c|c|c|c|c|c|c|c|c|}
\hline & Dec & Jan & Feb & Mar & Apr & May & Jun & Jul & Aug & Sep \\
\hline Guidance Documents ...... & & & & & & & & & & \\
\hline Gravel/BC & & & & & & & & & & \\
\hline Site Work Releases & & & & & & & & & & \\
\hline Technology Assessment Rpts - & & & & & & & & & & \\
\hline Preparedness Reviews & & & & & & & & & & \\
\hline Admin Trailer/CTP & & & & & & & & T & & \\
\hline Fire Extinquishers/CTP & & & & & & & & & & \\
\hline & & & & & & & & & & \\
\hline Generators/CTP & & & & & & & & & & \\
\hline Toilet/BC & & & & & & & & & & \\
\hline Toilet/CTP $\ldots . . .$. & & & & & & & & & & \\
\hline Bottled Water/BC -. & & & & & & & & & & \\
\hline Bottled Water/CTP & & & & & & & & & & \\
\hline Chemical Storage/BC & & & & & & & & & & \\
\hline Chemical Storage/CTP & & & & & & & & & & \\
\hline Trash Containers/BC & & & & & & & & & & \\
\hline Trash Containers/CTP & & & & & & & & & & \\
\hline $\mathrm{PPE} / \mathrm{BC}$ & & & & & & & & & & \\
\hline PPE/CTP & & & & & & & & & & \\
\hline Vehicles & & & & & & & & & & \\
\hline Construct Cells/CTP ..... & & & & & & & & & & \\
\hline Level Pad/BC & & & & & & & & & & \\
\hline Eye Wash/CTP ..... & & & & & & & & & & \\
\hline Tool Box/CTP & & & & & & & & & & \\
\hline Office Supplies/CTP & & & & & & & & & & \\
\hline Road and Ground Mainten/CTP & & & & & & & & & & \\
\hline Generator Maintenance -... & & & & & & & & & & \\
\hline Mobile Phone/CTP ........ & & & & & & & & & & \\
\hline Mobile Phone/BC ....... & & & & & & & & & & \\
\hline Photography Plan & & & & & & & & & & \\
\hline On-site support/BC & & & & & & & & & & \\
\hline On-site support/CTP & & & & & & & & & & \\
\hline Expo Support & & & & & & & & & & \\
\hline Site Restoration/BC & & & & & & & & & & \\
\hline Site Restoration/CTP -- & & & & & & & & & & \\
\hline
\end{tabular}

Figure 7. Deployment team activities schedule. 
Table 1. Schedule for technology assessments and preparedness reviews.

\begin{tabular}{lllll}
\hline \multicolumn{1}{c}{ Project } & \multicolumn{1}{c}{$\begin{array}{c}\text { Technology } \\
\text { evaluation }\end{array}$} & $\begin{array}{c}\text { Technology } \\
\text { assessment } \\
\text { report due date }\end{array}$ & $\begin{array}{c}\text { Technology } \\
\text { preparedness } \\
\text { review }\end{array}$ & Demonstration dates \\
\hline $\begin{array}{l}\text { Non-intrusive sensing } \\
\text { Tensor magn grad } \\
\text { Broadband }\end{array}$ & March 7, 1994 & March 21, 1994 & April 4, 1994 & April 11, 1994-May 13, 1994 \\
\multicolumn{1}{c}{ EM methods } & May 27, 1994 & June 13, 1994 & June 27, 1994 & July 5, 1994-August 31, 1994 \\
$\begin{array}{l}\text { Dig face characterization } \\
\text { Innovative grout }\end{array}$ & March 3, 1994 & March 17, 1994 & April 4, 1994 & April 11, 1994-April 29, 1994 \\
VETEM & May 10, 1994 & May 25, 1994 & June 13, 1994 & June 20, 1994-August 19, 1994 \\
Monolithic confinement & July 1, 1994 & July 18, 1994 & August 1, 1994 & August 8, 1994-August 19, 1994 \\
GPR testing & March 18, 1994 & April 1, 1994 & April 15, 1994 & May 1, 1994-May 27, 1994 \\
\hline
\end{tabular}


Table 2. Schedule for guidance and ESH\&Q plans.

\begin{tabular}{lcc}
\hline \multicolumn{1}{c}{ Report title } & Draft due date & Final due date \\
\hline TP\&SR Guidance & $12 / 6 / 93$ & $2 / 7 / 94$ \\
Goals and Test Objectives & $12 / 6 / 93$ & $1 / 31 / 94$ \\
Test Plan Guidance & $12 / 6 / 93$ & $1 / 31 / 94$ \\
Technology Evaluation Report Guidance & $12 / 6 / 93$ & $1 / 31 / 94$ \\
Project Management Plan & $12 / 20 / 93$ & $2 / 794$ \\
Deployment Plan & $1 / 27 / 94$ & $5 / 1 / 94$ \\
Tech Transfer/Comm Plan & $2 / 28 / 94$ & $3 / 15 / 94$ \\
Public Participation Plan & $2 / 28 / 94$ & $3 / 15 / 94$ \\
QPP & $2 / 28 / 94$ & $3 / 15 / 94$ \\
ESH\&Q Plan & $2 / 28 / 94$ & $5 / 1 / 94$ \\
Waste Min Plan & $3 / 16 / 94$ & $4 / 1 / 94$ \\
Program Manual & $12 / 1 / 93$ & $2 / 7 / 94$ \\
'95 Integrated Test Plan & $8 / 1 / 94$ & $10 / 1 / 94$ \\
\hline
\end{tabular}




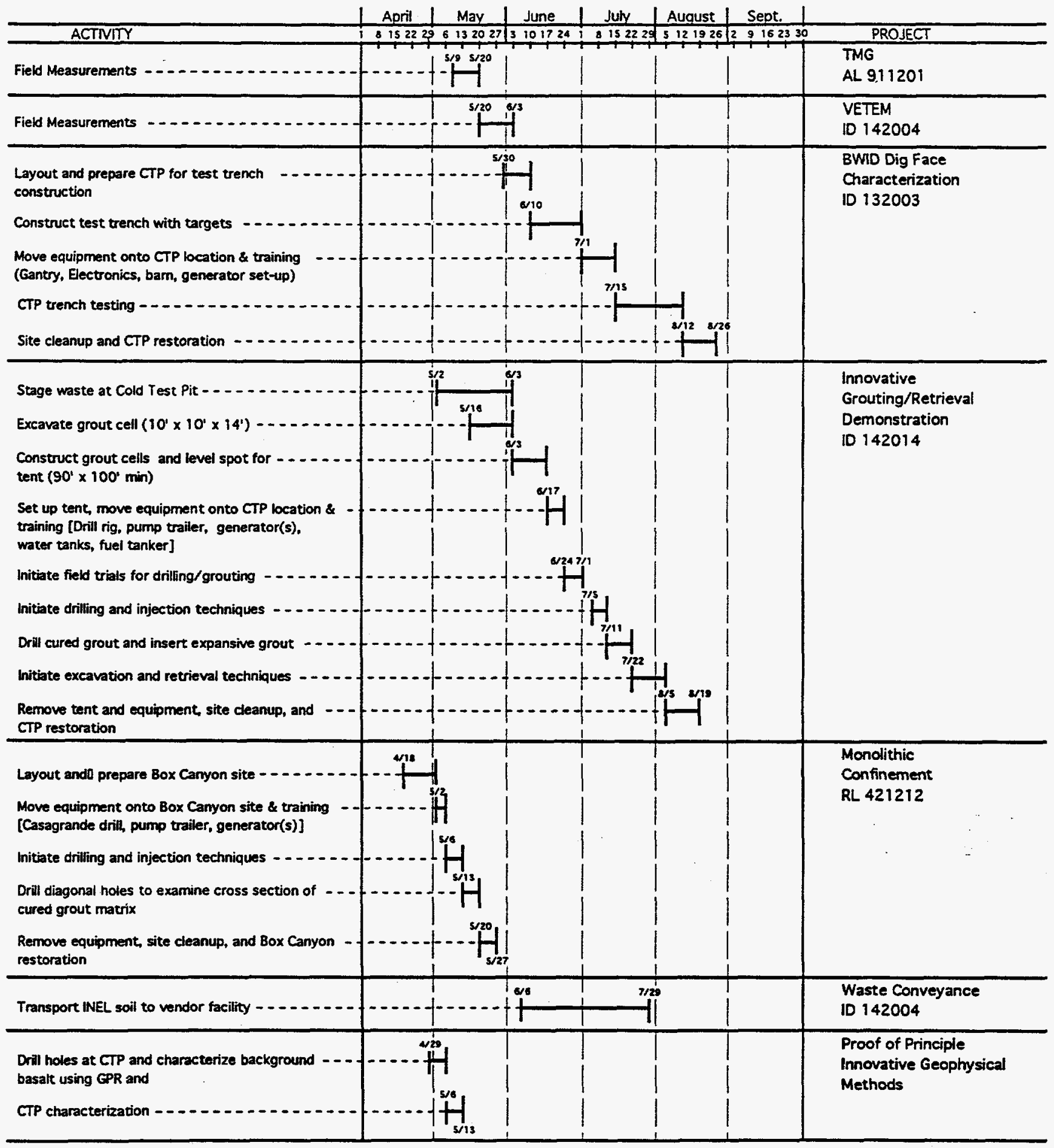

Figure 8. INEL field deployment schedule. 


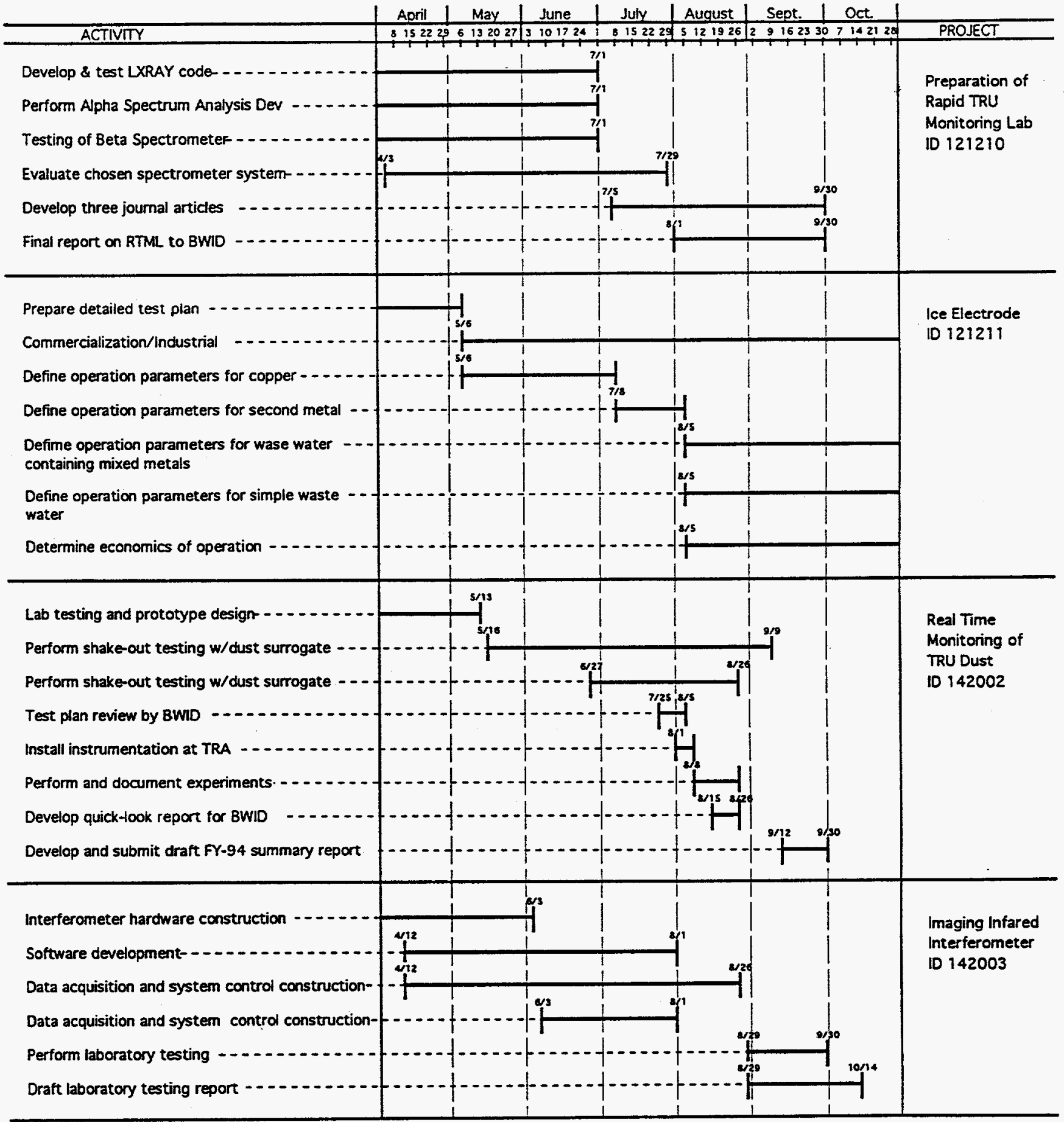

Figure 9. Laboratory test schedule. 


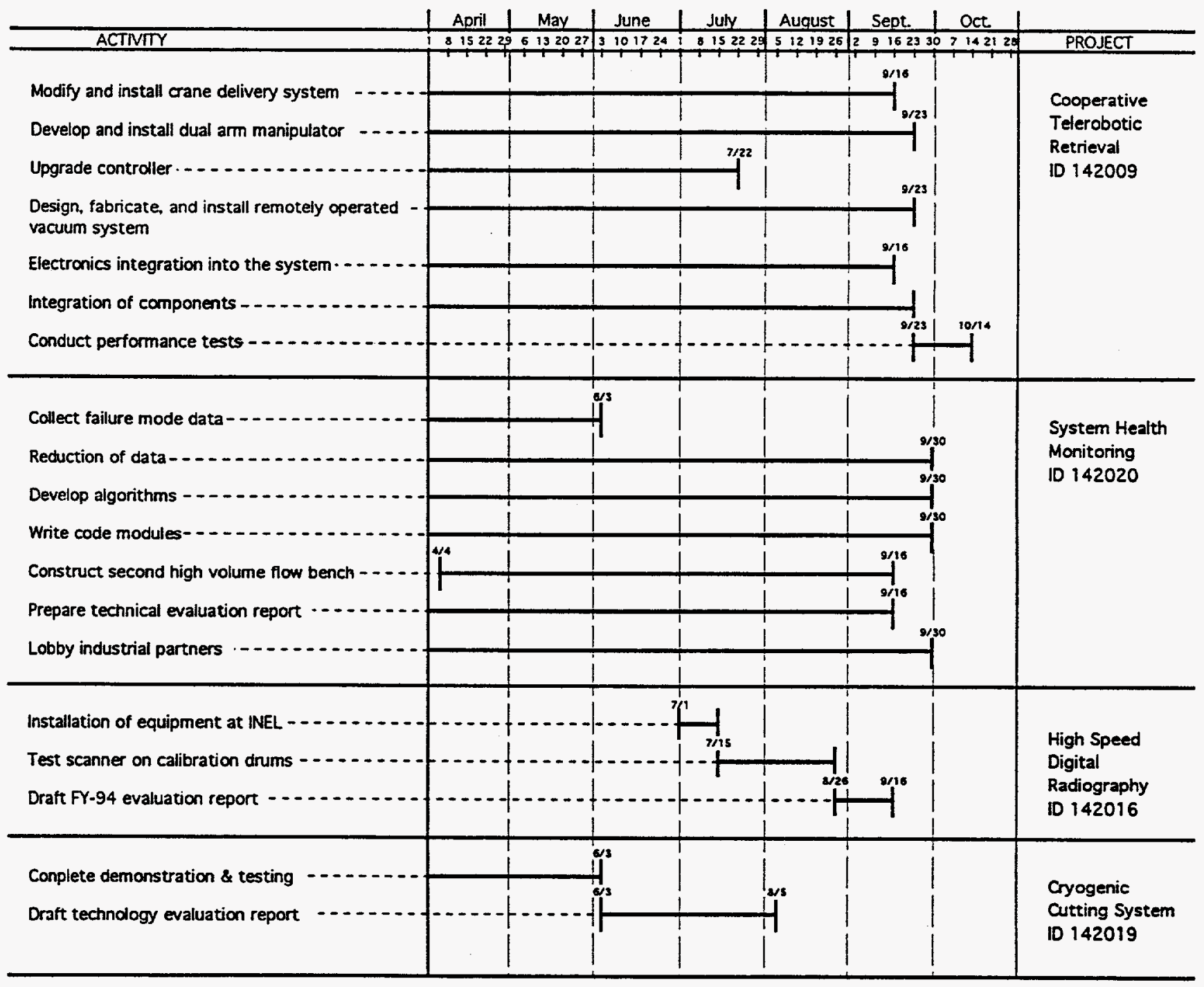

Figure 9. (continued). 


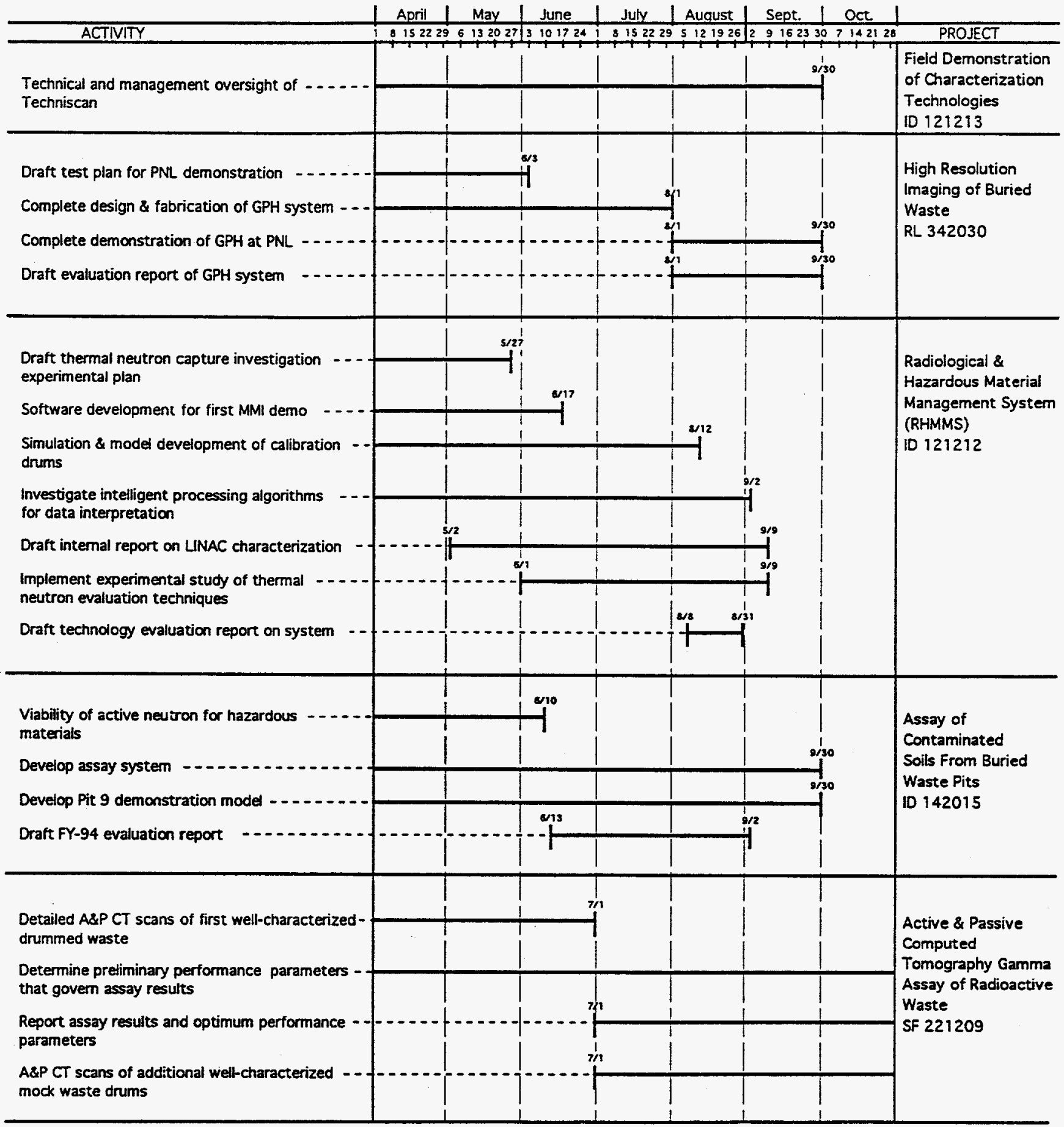

Figure 10. Non-INEL test schedule. 


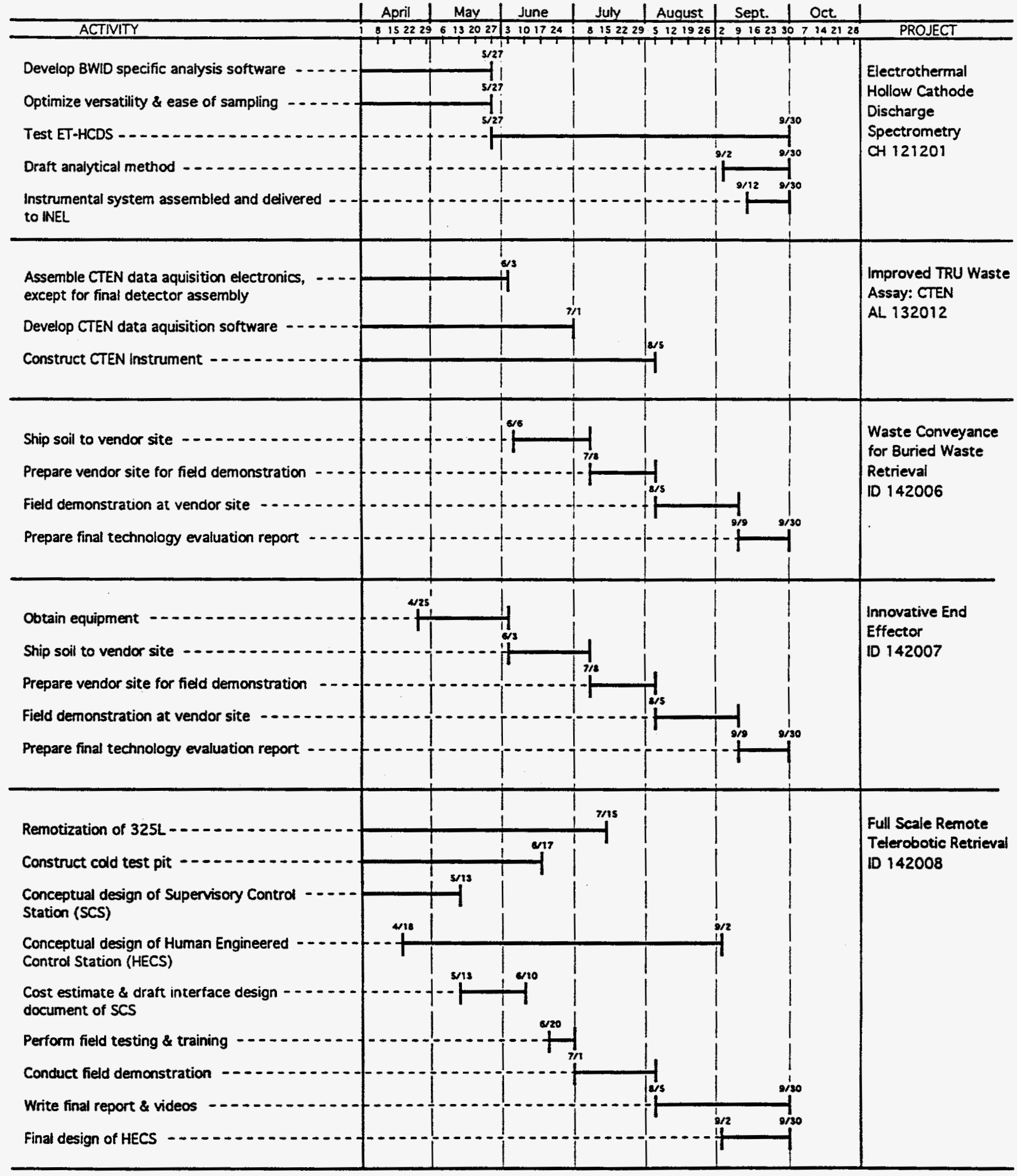

Figure 10. (continued). 


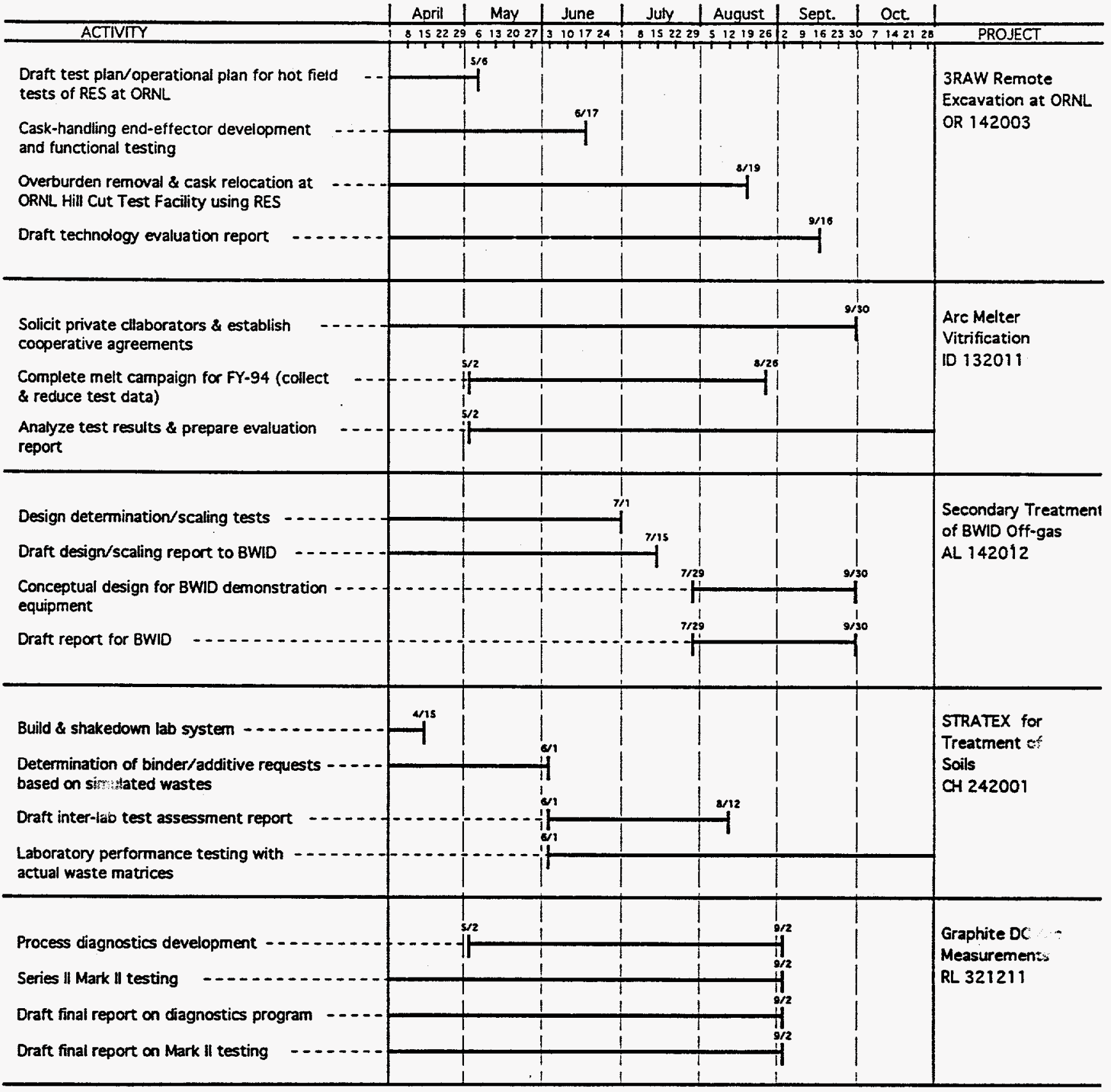

Figure 10. (continued). 


\section{REFERENCES}

1. EG\&G Idaho, Inc., Buried Waste Integrated Demonstration Program Technology Test Plan Guidance, EGG-WTD-9800.

2. EG\&G Idaho, Inc., Safety Manual.

3. EG\&G Idaho, Inc., Industrial Hygiene Manual.

4. EG\&G Idaho, Inc., RWMC Operational Safety Requirements Safety Analysis Report.

5. EG\&G Idaho, Inc., Conduct of Operations Manual.

6. EG\&G Idaho, Inc., Environmental Restoration Program Generic Health and Safety Plan.

7. EG\&G Idaho, Inc., Company Procedures Manual.

8. EG\&G Idaho, Inc., Radioactive Waste Management Complex Tenants Manual.

9. EG\&G Idaho, Inc., Training Requirements and Responsibilities for the Buried Waste Integrated Demonstration at the Radioactive Waste Management Complex, EGG-WTD-10400.

10. EG\&G Idaho, Inc., RWMC Emergency Plan/RCRA Contingency Plan. 